\title{
Revised Taxonomy of the Methanotrophs: Description of Methylobacter gen. nov., Emendation of Methylococcus, Validation of Methylosinus and Methylocystis Species, and a Proposal that the Family Methylococcaceae Includes Only the Group I Methanotrophs
}

\author{
JOHN P. BOWMAN, ${ }^{1}{ }^{*}{ }^{*}$ LINDSAY I. SLY, ${ }^{1}$ PETER D. NICHOLS, ${ }^{2}$ AND A. C. HAYWARD ${ }^{1}$ \\ Center for Bacterial Diversity and Identification, Department of Microbiology, The University of \\ Queensland, Brisbane, Queensland 4072, ${ }^{1}$ and CSIRO Marine Laboratories, Division of \\ Oceanography, Hobart, Tasmania $7001,{ }^{2}$ Australia
}

\begin{abstract}
Numerical taxonomic, DNA-DNA hybridization, and phospholipid fatty acid composition analyses were performed on an extensive range of methanotrophic strains, including reference strains and environmental isolates obtained from sites throughout eastern Australia. When the results of these studies were related to the results of a study based on genomic physicochemical properties, they clarified group I and II methanotroph genus and species interrelationships. The group I methanotrophs were found to be made up of three broadly phenotypically and genotypically homologous clusters of species. The first group I methanotroph cluster included the carotenoid-containing species Methylomonas methanica, Methylomonas fodinarum, and Methylomonas aurantiaca. These species represent the true members of the genus Methylomonas. The second group I methanotroph cluster was made up of two subclusters of strains. One subcluster included species not capable of producing resting cells and consisted of the species "Methylomonas agile," "Methylomonas alba," and Methylomonas pelagica. The other subcluster included species capable of forming desiccation-resistant cysts and included Methylococcus luteus, marine Methylomonas-like strains, and Methylococcus whittenburyi. Strains designated "Methylococcus ucrainicus" and Methylococcus vinelandii were found to be synonyms of Methylococcus whittenburyi, while Methylococcus bovis was a synonym of Methylococcus luteus. It is proposed that these subclusters represent a new genus, Methylobacter gen. nov. The species in the new genus are type species Methylobacter luteus comb. nov., Methylobacter agilis sp. nov., Methylobacter albus sp. nov., nom. rev., Methylobacter marinus sp. nov., Methylobacter pelagicus comb. nov., and Methylobacter whittenburyi comb. nov. The remaining group I methanotrophs included the moderately thermophilic species Methylococcus capsulatus and Methylococcus thermophilus and a group of unnamed strains closely related to Methylococcus capsulatus. It is proposed that these species represent the true members of the genus Methylococcus. The group II methanotrophs consisted of two closely related groups. The first group included budding, exosporeproducing strains, while the second group included nonmotile, cyst-forming strains. These groups represent the genera Methylosinus and Methyocystis, which are revived here. The genus Methylosinus gen. nov., nom. rev. includes the species Methylosinus trichosporium sp. nov., nom. rev. and Methylosinus sporium sp. nov., nom. rev., while the genus Methylocystis gen. nov., nom. rev. includes the species Methylocystis parvus sp. nov., nom. rev. and Methylocystis echinoides sp. nov., nom. rev.
\end{abstract}

The methanotrophs represent a subset of gram-negative, obligately methylotrophic bacteria that utilize methane as their primary source of carbon and energy. The difficulty in obtaining pure cultures, the lack of discriminating phenotypic characteristics, and transgressions against the International Code of Nomenclature of Bacteria $(30,56)$ have resulted in classification problems in methanotroph taxonomy.

The methanotrophs can be separated into two assemblages, which are usually referred to as types or groups I and II (56). To avoid confusion with such concepts as type strain, type species, etc., in this study we used the terms group I and group II. The group I and II methanotrophs differ in their intracytoplasmic membrane ultrastructures, carbon assimi-

\footnotetext{
* Corresponding author.

$\uparrow$ Present address: Center for Environmental Biotechnology, The University of Tennessee, 10515 Research Dr., Suite 100, Knoxville, TN 37932 .
}

lation pathways, fatty acid carbon chain lengths (56), and phylogeny (52). In various studies an additional group of methanotrophs, referred to as group $\mathrm{X}$, has also been described $(23,26)$. Originally, the group $X$ methanotrophs were defined on the basis of $\mathrm{G}+\mathrm{C}$ values and intracytoplasmic membrane contents (36) and only included some members of the group I methanotroph genus Methylococcus. Subsequently, other characteristics have been used to further define this group (26). In this study the term group $\mathrm{X}$ was not used to avoid confusion.

Currently, the methanotrophs with valid taxonomic status include only the group I methanotrophs (37) assigned to the genera Methylococcus (20) and Methylomonas (56). The group II methanotrophs, which include the genera "Methylocystis" and "Methylosinus" $(43,57)$, have no standing in bacterial nomenclature (37). Even among the officially recognized genera considerable heterogeneity exists. Genomic characteristics, including $\mathrm{G}+\mathrm{C}$ values, genome molecular weights, and DNA melting transition widths, separate the 
genus Methylococcus into two distinct clusters of species (7). These clusters also contain a number of Methylomonas species. One cluster of Methylococcus species includes the moderately thermophilic species Methylococcus capsulatus (20), Methylococcus thermophilus, and "Methylomonas gracilis"' $(35,43)$. The $\mathrm{G}+\mathrm{C}$ values for these species vary from 59 to $66 \mathrm{~mol} \%$. The members of the second Methylococcus species cluster are mesophilic and have lower $\mathrm{G}+\mathrm{C}$ contents (range, 48 to $55 \mathrm{~mol} \%)(7,34-36)$, and this cluster includes Methylococcus bovis, Methylococcus luteus, Methylococcus vinelandii, and Methylococcus whittenburyi (43). Romanovskaya (42) attempted to resolve this heterogeneity by placing the mesophilic low-G $+\mathrm{C}$-content Methylococcus species in a different genus, the genus "Methylovarius." This genus name is currently invalid (37). The results of DNA-DNA hybridization studies performed by Lysenko et al. (34) suggested that all of these species except Methylococcus luteus are closely related. This phenotypic and genotypic ambiguity still remains to be resolved for the species of this group. The species "Methylomonas alba" (43) and Methylomonas pelagica (45) were also found to be similar to the mesophilic low-G+C-content Methylococcus species on the basis of genomic characteristics (7). The remaining Methylomonas species, Methylomonas methanica (56), Methylomonas aurantiaca, and Methylomonas fodinarum (6), are distinct in terms of their genomic characteristics (7) and characteristically produce carotenoid pigments. The species "Methylomonas agile" (57) appeared to have genomic characteristics similar to those of the carotenoid-containing Methylomonas species. However, phenotypically, "Methylomonas agile" appears to be more closely related to "Methylomonas alba" and does not produce carotenoid pigments.

The results of comparisons of the $5 \mathrm{~S}$ rRNA sequences of Methylomonas and Methylococcus species $(10,11)$ also indicated that the taxonomy of these genera and species requires clarification and revision. For instance, genomic characteristics (7) and the results of 5S rRNA (10) and 16S rRNA sequence analyses (9) suggest that the group II methanotroph genera "Methylosinus" and "Methylocystis" are closely related but distinctly different groups. However, the phenotypic and genotypic homogeneity among the group II methanotrophs is still to be defined. We found that on the basis of the results of a comprehensive phenotypic survey of several reference methanotroph strains and environmental isolates, accompanied by the results of DNA-DNA hybridization and fatty acid analyses, it was possible to elucidate methanotroph genus and species interrelationships. In this study we established a foundation for an effective systematics for the methanotrophs.

\section{MATERIALS AND METHODS}

Bacterial strains and cultivation. The strains investigated in this study are listed in Table 1 . These strains were grown under a methane-air- $\mathrm{CO}_{2}(5: 4: 1)$ atmosphere. All of the strains except Methylomonas sp. strains A1, A4, and C2 and Methylomonas pelagica ACM $3505^{\mathrm{T}}$ ( $\mathrm{T}=$ type strain) were cultivated on nitrate-mineral salts (NMS) agar (6). Methylomonas sp. strains $\mathrm{A} 1, \mathrm{~A} 4$, and $\mathrm{C} 1$ (33) were grown at $37^{\circ} \mathrm{C}$ on NMS medium prepared with tap water and supplemented with $0.5 \%$ (wt/vol) $\mathrm{NaCl}$ and $5 \mathrm{ml}$ of a vitamin solution (50) per liter. Methylomonas pelagica $\mathrm{ACM} 3505^{\mathrm{T}}$ was cultivated at $25^{\circ} \mathrm{C}$ on NMS medium prepared with artificial seawater (from Marine agar 2216 [catalog no. 0979; Difco] and solidified with $1.0 \%$ (wt/vol) agarose (type V; Sigma Chemical Co., St. Louis, Mo.) (45). The Methylococcus strains in phena 10 through 12 (Table 1 ) were cultivated at $45^{\circ} \mathrm{C}$, and the other strains in Table 1 were grown at $28^{\circ} \mathrm{C}$. The methods used for isolation and purification of methanotrophs have been described previously by Bowman et al. (6). The guidelines described by Lidstrom (33) for determining the purity of methanotroph cultures were followed.

Morphological observations. The Gram stain reaction and the results of the correlative tests, which included aminopeptidase production, lysis in $10 \%$ (wt/vol) sodium dodecyl sulfate (SDS), and lysis in $3 \%$ (wt/vol) $\mathrm{KOH} \mathrm{(47),} \mathrm{were}$ determined by using 7-day-old cultures. Microcolonies on NMS medium containing Noble agar (catalog no. 0142; Difco) were observed after $24 \mathrm{~h}$ by using oil immersion phase-contrast microscopy. The presence of rosettes and exospore formation were verified by this procedure. Capsules were stained with $2.5 \%$ (wt/vol) nigrosine (15) and observed by using oil immersion phase-contrast microscopy. Growth from 14-day-old NMS medium cultures was stained by the procedure of Vela and Wyss (53) and with the Ziehl-Neelsen stain (15) and was observed microscopically for the presence of Azotobacter-like cysts. The presence of exospores was ascertained by determining the viability of strains after suspensions of 7-day-old NMS medium cultures were heated at $80^{\circ} \mathrm{C}$ for $20 \mathrm{~min}$ by using a heating block (model DB3 Dri-block, Tecam). The presence of exospores was then confirmed by observing microcolonies of the viable and thus heat-resistant strains. Desiccation resistance was assessed by the method described by Whittenbury et al. (55). The presence of poly- $\beta$-hydroxybutyrate inclusions was determined chemically (25), and polyphosphate (volutin) was detected by a modification of the method of Neisser (16). Colony morphology and pigmentation were determined by using 7-day-old NMS agar plate cultures.

Electron microscopy. Flagellum insertion was determined by examining negatively stained or metal-shadowed cells with an Hitachi model $\mathrm{H}-800$ transmission electron microscope. The negative stain utilized was phosphotungstate $(1 \%, \mathrm{wt} / \mathrm{vol} ; \mathrm{pH} 6.5)$. The cells were shadowed with $1.7 \mathrm{~nm}$ of platinum-carbon from an electron gun at an angle of $30^{\circ}$ in a vacuum of approximately $10^{-5}$ torr $\left(133 \times 10^{-5} \mathrm{~Pa}\right)$, using a high-vacuum coating unit (Balzers Aktiengesellschaft, Fürstentum, Liechtenstein). Thin sections of cells taken from 3-day-old liquid or plate cultures were used to determine intracytoplasmic membrane types. The ruthenium red staining procedures of Fassel et al. (19) and Pierson et al. (40) were used to process the samples.

Physiological tests. The following tests were performed by the rapid titer tray method of Cox and MacRae (13): growth at $\mathrm{pHs}$ ranging from 4.0 to 10.0 ; growth at various temperatures ranging from 4 to $60^{\circ} \mathrm{C}$; tolerance to $\mathrm{NaCl}$ at concentrations ranging from 0.5 to $5.0 \%$ (wt/vol); and tolerance to $0.0075 \%$ (wt/vol) $\mathrm{KCN}, 0.01 \%$ (wt/vol) $\mathrm{NaN}_{3}$, and $0.01 \%$ (wt/vol) SDS. The titer trays were incubated under a methane-air $(1: 1)$ atmosphere in desiccators. Tolerance to dyes was tested by incorporating dyes into NMS agar plates; the dyes tested included $0.001 \%$ crystal violet, $0.001 \%$ malachite green, and $0.01 \%$ methylene blue.

Carbon and nitrogen source utilization. NMS medium was used as the basal medium to determine utilization of the following carbon sources at a concentration of $0.1 \%$ : ethanol, formate, formamide, urea, methanol, methylamine, dimethylamine, trimethylamine, tetramethylammonium chloride, trimethylamine $\mathrm{N}$-oxide, trimethyl $\mathrm{N}$-sulfonium iodide, and dimethylcarbonate. Volatile liquid carbon sources and $\mathrm{C}_{1}$ compounds were filter sterilized and added after autoclaving to the basal medium, which was then 
TABLE 1. Methanotrophic strains investigated in this study

\begin{tabular}{|c|c|c|c|}
\hline Phenon $^{a}$ & Taxon & Strain $(\mathbf{s})^{b}$ & Source or isolation site $\mathrm{e}^{b, c}$ \\
\hline \multirow[t]{6}{*}{1} & Methylomonas methanica & $\underset{\left.10543^{\mathrm{T}}\right)}{\operatorname{ACM} 3307^{\mathrm{T}}}\left(=\mathrm{S}^{\mathrm{T}}=\mathrm{NCIMB} 11130^{\mathrm{T}}=\operatorname{ATCC} 35067^{\mathrm{T}}=\operatorname{IMET}\right.$ & NCIMB \\
\hline & & JB5, JB9, JB17, JB227 & Coal mine drainage water \\
\hline & & JB40 & Soil \\
\hline & & JB182, JB193, JB194, JB195 & Creek mud \\
\hline & & JB228 & River mud \\
\hline & "Methylomonas rubra" & ACM 3303 (= NCIMB 11913 = VKM-15m) & NCIMB \\
\hline 2 & Methylomonas fodinarum & $\begin{array}{l}\text { JB2, JB3, JB4, JB6, JB7, JB10, ACM } 3268^{\mathrm{T}}\left(=\mathrm{JB} 13^{\mathrm{T}}\right), \mathrm{JB} 15 \\
\text { JB34, JB37, JB70 }\end{array}$ & $\begin{array}{l}\text { Coal mine drainage water } \\
\text { Lake sediment }\end{array}$ \\
\hline \multirow[t]{4}{*}{3} & Methylomonas aurantiaca & JB25, JB27 & Waterlogged soil \\
\hline & & $\begin{array}{l}\text { JB96, JB97, JB98, JB99, JB100, JB101, JB102, ACM 3406 }{ }^{\mathrm{T}} \\
\left(=\mathrm{JB} 103^{\mathrm{T}}\right), \mathrm{JB} 104, \mathrm{JB} 105, \mathrm{JB} 106, \mathrm{JB} 114, \mathrm{JB} 121, \mathrm{JB} 122, \mathrm{JB} 126\end{array}$ & $\begin{array}{l}\text { Sewage sludge and } \\
\text { wastewater }\end{array}$ \\
\hline & & JB129, JB134, JB135, JB142 & River mud \\
\hline & & JB176, JB177a, JB177b, JB178a, JB178b, JB179a, JB179b & Lake sediment \\
\hline \multirow[t]{6}{*}{4} & Methylococcus bovis & IMET 10593 & IMET \\
\hline & Methylococcus sp. & JB50 & Lake sediment \\
\hline & & JB200 & Coal mine drainage water \\
\hline & "Methylococcus ucrainicus" & ACM 3305 (= NCIMB 11915 = VKM-160) & NCIMB \\
\hline & Methylococcus vinelandii & ACM $3586^{\mathrm{T}}\left(=\mathrm{IMV}-\mathrm{B} 3030^{\mathrm{T}}=\mathrm{VKM}-248^{\mathrm{T}}\right)$ & IMV \\
\hline & Methylococcus whittenburyi & $\operatorname{ACM} 3310^{\mathrm{T}}\left(=\right.$ NCIMB $\left.11128^{\mathrm{T}}\right)$ & NCIMB \\
\hline 5 & Methylomonas sp. (marine) & $\mathrm{A} 1, \mathrm{~A} 45, \mathrm{C} 1$ & Lidstrom \\
\hline 6 & "Methylomonas agile" & $\begin{array}{l}\text { ACM } 3308^{\mathrm{T}}\left(=\text { NCIMB } 11124^{\mathrm{T}}=\text { ATCC } 35068^{\mathrm{T}}\right) \\
\text { JB109 }\end{array}$ & $\begin{array}{l}\text { NCIMB } \\
\text { Sewage }\end{array}$ \\
\hline \multirow[t]{2}{*}{7} & "Methylomonas alba" & ACM $3314^{\mathrm{T}}\left(=\right.$ NCIMB $11123^{\mathrm{T}}=$ IMET $\left.10526^{\mathrm{T}}=\mathrm{VKM}-\mathrm{BG} 8^{\mathrm{T}}\right)$ & NCIMB \\
\hline & & $\begin{array}{l}\text { JB160, JB161 } \\
\text { JB162, JB163, JB164, JB166, JB168 }\end{array}$ & Soil \\
\hline \multirow{3}{*}{8} & Methylococcus luteus & $\begin{array}{l}\mathrm{JB162}, \mathrm{JB}^{\mathrm{T}} \text {, JB164, JB166, }{ }^{\mathrm{B}} 168 \\
\mathrm{ACM} 3304^{\mathrm{T}}\left(=\mathrm{NCIMB} 11914^{\mathrm{T}}=\mathrm{VKM}-53 \mathrm{~B}^{\mathrm{T}}\right)\end{array}$ & $\begin{array}{l}\text { Creek mud } \\
\text { NCIMB }\end{array}$ \\
\hline & & $\begin{array}{l}\text { ACM 3304 } \\
\text { JB107, JB108 }\end{array}$ & $\begin{array}{l}\text { NCIMB } \\
\text { Sewage }\end{array}$ \\
\hline & Methylococcus bovis & IMV-B-3098 ${ }^{\mathrm{T}}\left(=\mathrm{VKM}-6^{\mathrm{T}}\right)$ & IMV \\
\hline 9 & Methylomonas pelagica & NCIMB $2265^{\mathrm{T}}$ & NCIMB \\
\hline \multirow[t]{6}{*}{10} & Methylococcus capsulatus & $\operatorname{ACM} 1292^{\mathrm{T}}\left(=\right.$ ATCC $\left.19069^{\mathrm{T}}=\operatorname{NCIMB} 11853^{\mathrm{T}}\right)$ & ATCC \\
\hline & & $\begin{array}{l}\text { ACM } 3302(=\text { NCIMB } 11132=\text { ATCC } 33009=\text { IMET } 10544= \\
\text { VKM-TRMC })\end{array}$ & NCIMB \\
\hline & & $\mathrm{JB} 115, \mathrm{JB} 116$ & Sewage \\
\hline & & JB120, JB137 & River mud \\
\hline & & JB146 & Marsh mud \\
\hline & & JB175 & Lake sediment \\
\hline \multirow[t]{4}{*}{11} & Methylococcus sp. & JB41, JB43 & Creek mud \\
\hline & & JB56, JB57 & Soil \\
\hline & & JB83, JB84, JB86, JB87 & Marsh mud \\
\hline & & JB131, JB138, JB139, JB140, JB141, JB143, JB144, JB145, JB173 & River mud \\
\hline \multirow[t]{4}{*}{12} & Methylococcus thermophilus & ACM $3585^{\mathrm{T}}\left(=\mathrm{IMV}-\mathrm{B} 3037^{\mathrm{T}}=\mathrm{VKM}-2 \mathrm{Yu}^{\mathrm{T}}\right)$ & IMV \\
\hline & & JB174 & Lake sediment \\
\hline & & JB180, JB187 & Soil \\
\hline & & JB181, JB185 & Creek mud \\
\hline 13 & "Methylosinus trichosporium" & ACM $3311^{\mathrm{T}}\left(=\operatorname{NCIMB} 11131^{\mathrm{T}}=\right.$ ATCC $\left.35070^{\mathrm{T}}=\operatorname{IMET} 10541^{\mathrm{T}}\right)$ & NCIMB \\
\hline \multirow[t]{2}{*}{14} & "Methylosinus sporium" & ACM $3306^{\mathrm{T}}\left(=\right.$ NCIMB $11126^{\mathrm{T}}=$ ATCC $35069^{\mathrm{T}}=$ IMET $\left.10545^{\mathrm{T}}\right)$ & NCIMB \\
\hline & & JB153, J5154, JB159, JB203, JB205, JB206, JB207 & Rice soil \\
\hline \multirow[t]{7}{*}{15} & “Methylocystis parvus & ACM $3309^{\mathrm{T}}\left(=\right.$ NCIMB $11129^{\mathrm{T}}=$ ATCC $35066^{\mathrm{T}}=$ IMET $\left.10483^{\mathrm{T}}\right)$ & NCIMB \\
\hline & & JB21 & Coal mine drainage water \\
\hline & & JB22, JB47, JB48, JB51, JB52 & Soil \\
\hline & & JB29, JB30 & Raw water \\
\hline & & JB33 & Lake sediment \\
\hline & & JB190 & Marsh mud \\
\hline & & JB191, JB192, JB196, JB198 & Creek mud \\
\hline 16 & "Methylocystis echinoides" & IMET $10491^{\mathrm{T}}$ & IMET \\
\hline
\end{tabular}

${ }^{a}$ See Fig. 1 for location on dendrogram.

b Abbreviations: ACM, Australian Collection of Microorganisms, The University of Queensland, Brisbane, Australia; ATCC, American Type Culture Collection, Rockville, Md.; IMET, Institute of Medical and Experimental Therapy, Jena, Germany; NCIMB, National Collection of Industrial and Marine Bacteria, Aberdeen, United Kingdom. VKM, All-Union Culture Collection of Microorganisms, Academy of Sciences, Moscow, Russia; IMV, V. A. Romanovskaya, Institute of Microbiology and Virology, Academy of Sciences, Kiev, Ukraine; Lidstrom, M. E. Lidstrom, California Institute of Technology, Pasadena, Calif.

$c$ The methods used for enrichment and isolation of environmental methanotrophic isolates are described in reference 6 .

dispensed in 10-ml volumes into screw-cap test tubes (Wheaton, Inc., Millville, N.J.). The following carbon sources were tested by the rapid titer tray method (13): D-arabinose, D-xylose, D-fructose, D-glucose, acetate, DL- lactate, sebacate, DL-tartrate, citrate, L-aspartate, L-glutamate, and betaine. Controls lacking a carbon substrate and nutrient broth controls were included to guard against the possibility that mixed methanotroph cultures might cause 
false-positive results. Nitrogen sources were tested similarly by using NMS medium in which the sodium nitrate was replaced with one of the following compounds at a concentration of $0.1 \%$ : sodium nitrite, ammonium sulfate, hydroxylamine hydrochloride, glycine, DL-alanine, L-serine, L-threonine, L-valine, L-leucine, L-isoleucine, L-proline, L-cysteine, L-methionine, L-glutamate, L-aspartate, L-glutamine, L-asparagine, L-histidine, L-phenylalanine, Ltryptophan, L-arginine, L-lysine, L-ornithine, L-citrulline, 2-aminobutyrate, 4-aminobutyrate, 2-aminovalerate, 5-aminovalerate, putrescine, spermine, histamine, ethanolamine, $\alpha$-amylamine, betaine, creatine, hippurate, yeast extract, and Casamino Acids. Utilization of methylamine, dimethylamine, trimethylamine, trimethylamine $\mathrm{N}$-oxide, tetramethylammonium chloride, trimethylsulfonium iodide, and formamide as nitrogen sources was tested in test tubes instead of titer trays. All test preparations were incubated for 30 days in duplicate. Growth was confirmed by comparison with negative controls and by spectrophotometry at $A_{600}$. The titer trays were examined by using a Titertek titer tray reader at $600 \mathrm{~nm}$.

Biochemical tests. Catalase and oxidase activities were determined as described by Smibert and Krieg (47). Nitrate reduction and denitrification activity were tested in semisolid NMS medium containing $0.2 \%$ (wt/vol) $\mathrm{KNO}_{3}$. The semisolid medium was dispensed into test tubes $(10 \mathrm{ml}$ per tube); each tube also contained an inverted Durham tube. Nitrite was detected by diazotization (25). Nitrogen fixation was assayed by using the modified acetylene reduction procedure of Takeda (51). Hydrogen autotrophy was determined by the procedure of Sly (46), using liquid and semisolid NMS media as the growth media. Urease production was determined by observing alkalinization of NMS medium supplemented with $0.2 \%$ (wt/vol) urea and $0.005 \%$ (wt/vol) phenol red. Thiosulfate:cyanide sulfurtransferase activity (rhodanese test) was assayed by the procedure described by Lanyi (29). The presence of phosphatase and the presence of arylsulfatase were determined by the method of Jenkins and Jones (28), except that the basal medium used was NMS medium. Acid production from D-glucose was tested by supplementing NMS medium with $1.0 \%$ (wt/vol) glucose and $0.005 \%$ (wt/vol) bromothymol blue. Indole production from tryptophan was tested by supplementing NMS medium with $0.1 \%$ (wt/vol) L-tryptophan and using Ehrlich's reagent (4-dimethylaminobenzaldehyde in $70 \%$ [vol/vol] ethanol, 1.5 $\mathrm{M} \mathrm{HCl}$ (29). Esculin hydrolysis was determined by supplementing liquid NMS medium with $0.1 \%$ (wt/vol) esculin and $0.005 \%$ (wt/vol) ferric citrate (47). Reduction of 2,3,5-triphenyl-2H-tetrazolium chloride $(0.01 \%$, wt/vol), reduction of potassium tellurite $(0.1 \%$, wt/vol), and reduction of sodium selenite $(0.1 \%$, wt/vol) were determined in NMS agar.

Enzyme assays. Selected methanotroph isolates were grown on NMS medium for 3 to 4 days, harvested into 10 $\mathrm{mM}$ Tris ( $\mathrm{pH} 7.0$ ) buffer, and then washed twice by centrifugation at $10,000 \times g$ for $10 \mathrm{~min}$ at $4^{\circ} \mathrm{C}$. The cells, chilled in ice, were disrupted by three to five 20 -s pulses of ultrasonication with a model 250 Sonifier (Branson, Danbury, Conn.) at the maximum power setting $(250 \mathrm{kHz})$. The cell debris was removed by centrifugation at $20,000 \times g$ for $30 \mathrm{~min}$ at $4^{\circ} \mathrm{C}$. The activities of the following enzymes were assayed by using the resulting cell extract: hydroxypyruvate reductase (EC 1.1.1.29) (31), hexulose phosphate synthase (14), hydroxylamine cytochrome $c$ oxidoreductase (EC 1.7.3.4) (49), and ribulose-1,5-diphosphate carboxylase (EC 4.1.1.39) (1). The assays were performed with a model DU-8 spectrophotometer (Beckman Instruments, Fullerton, Calif.) at $25^{\circ} \mathrm{C}$.
Numerical taxonomy. Results were encoded in a binomial format (41). Data were analyzed by using the Taxan program (version 3.0) (Information Resources Group, Maryland Institute of Biotechnology, University of Maryland, College Park) and an IBM-compatible personal computer. Jaccard coefficients $\left(S_{J}\right)$ were used, and a similarity matrix was prepared by the unweighted pair group average procedure (48).

DNA-DNA hybridization analysis. DNAs were extracted from methanotrophs by procedures described by Bowman et al. (7). The spectrophotometric thermal renaturation procedure of Huss et al. (27) was used to determine levels of DNA homology between selected strains. $\mathrm{G}+\mathrm{C}$ values determined from the optimum renaturation temperatures were calculated as described by Bowman et al. (7).

PLFA profiles. To determine phospholipid fatty acid (PLFA) profiles, the total lipids of lyophilized cell material were extracted and fractionated with activated silicic acid $(24,54)$. The phospholipid fraction was transesterified to the corresponding methyl esters by using acid methanolysis and was analyzed by high-resolution gas chromatography (39). Fatty acid isomers and double-bond positions were determined by dimethyldisulfide derivitization $(17,38)$ and analysis by gas chromatography-mass spectrometry.

\section{RESULTS}

Numerical analysis. A total of 124 characters for 136 methanotrophic strains were included in the numerical analysis. When a cutoff similarity value $\left(S_{J}\right)$ of $\geq 72 \%$ was used to group the strains (Fig. 1), a total of 16 phena were formed. The assignments of individual strains to phena are shown in Table 1. The phenotypic results obtained for each of the phena are shown in Table 2 . Tentative identification of many environmental isolates could be made as these isolates were found to be very similar to reference strains. The group I methanotrophs were divided into phena 1 to 12 , while the group II methanotrophs were divided into phena 13 to 16 . Broader groups of phena were also discernable at a similarity value of $50 \%$ (Fig. 1).

The group I methanotrophs formed three such groups. The first of these included phena 1 to 3 and contained the pink and orange carotenoid-containing species Methylomonas methanica, Methylomonas fodinarum, and Methylomonas aurantiaca, respectively. These species were closely allied phenotypically, clustering together at an $S_{J}$ value of $\geq 69 \%$ (Fig. 1), and had the following general properties: coccobacillary or rod-shaped cells which were encapsulated, contained poly- $\beta$-hydroxybutyrate inclusions, non-desiccationresistant cysts, and carotenoid pigments, and were motile by means of a single polar flagellum. More detailed phenotypic traits that distinguish these species are shown in Table 2 .

A greater degree of phenotypic diversity was found in the second large group, which encompassed phena 4 to 9 (which clustered together at a similarity level of $\geq 55 \%$ ). A number of desiccation-resistant, cyst-producing (55) Methylococcus species were clustered in this group, including "Methylococcus ucrainicus" (phenon 4), Methylococcus vinelandii (phenon 4), Methylococcus whittenburyi (phenon 4), Methylococcus bovis (phenon 8), and Methylococcus luteus (phenon 8). Closely clustering with phenon 4 at an $S_{J}$ value of $\geq 64 \%$, phenon 5 contained three Methylomonas-like strains (strains $\mathrm{A} 1, \mathrm{~A} 4$, and $\mathrm{C1}$ ) which were isolated from seawater by Lidstrom (33) and were also capable of forming desiccationresistant cysts. These strains differed from phenon 4 strains in that they required $\mathrm{NaCl}$ for growth and also required an 


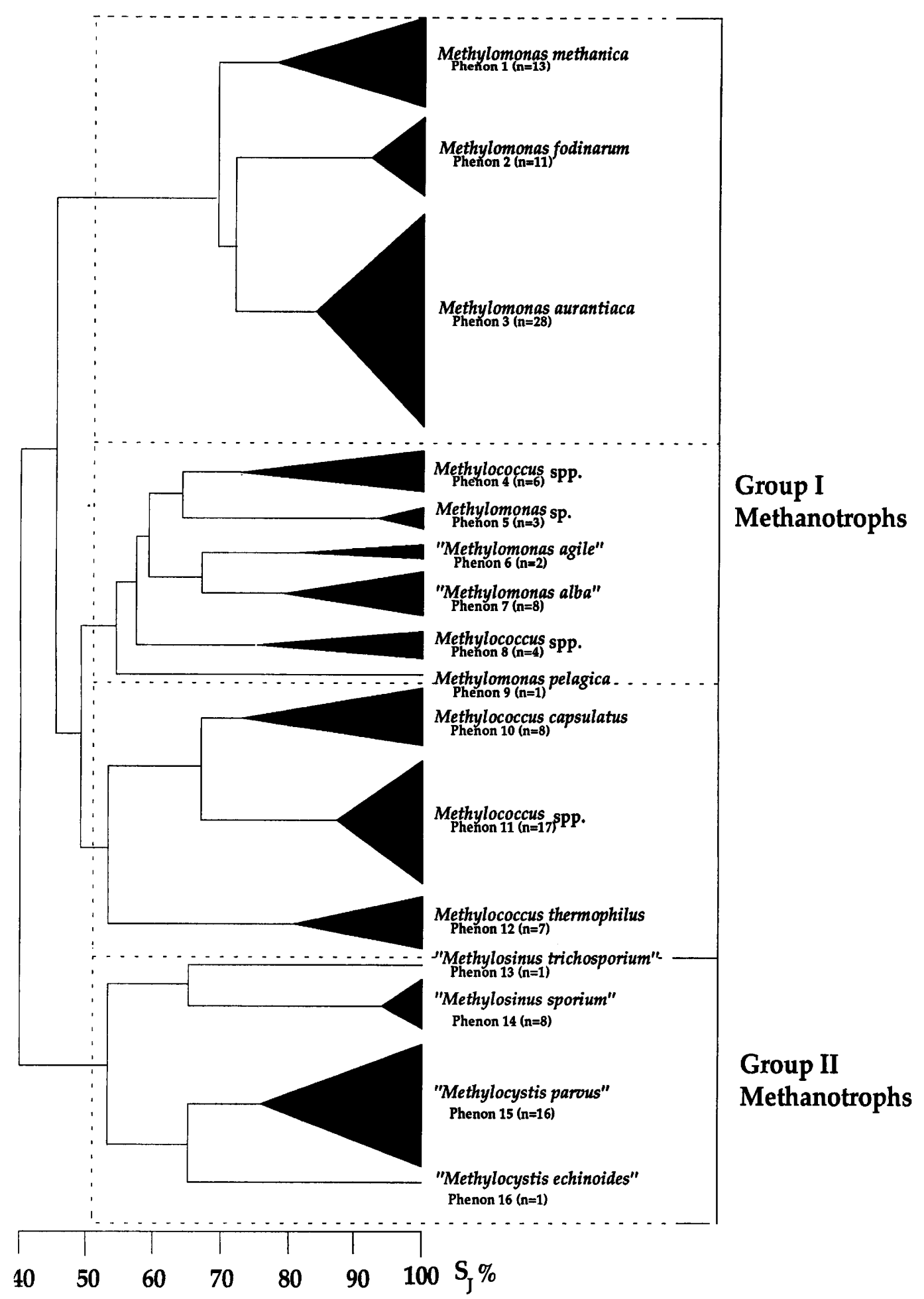

FIG. 1. Simplified dendrogram based on the results of a numerical analysis of 124 phenotypic characteristics of 136 methanotrophic bacteria. $S_{J}$ values were generated and clustered by using the unweighted pair group average procedure and the Taxan computer program. $\mathrm{n}$ is the number of strains in a cluster.

unidentified component present in tap water (33); otherwise, phenon 5 strains were morphologically and biochemically similar to phenon 4 strains (Table 2). In addition to the desiccation-resistant cyst-forming Methylococcus species, a number of Methylomonas species were also present in the second broad group (phena 6, 7, and 9). These strains differed from the Methylococcus species in phena 4, 5, and 8, having a more rodlike shape, and completely lacked a differentiated encystement stage. Phena 6, 7, and 9 included the species "Methylomonas agile," "Methylomonas alba," 


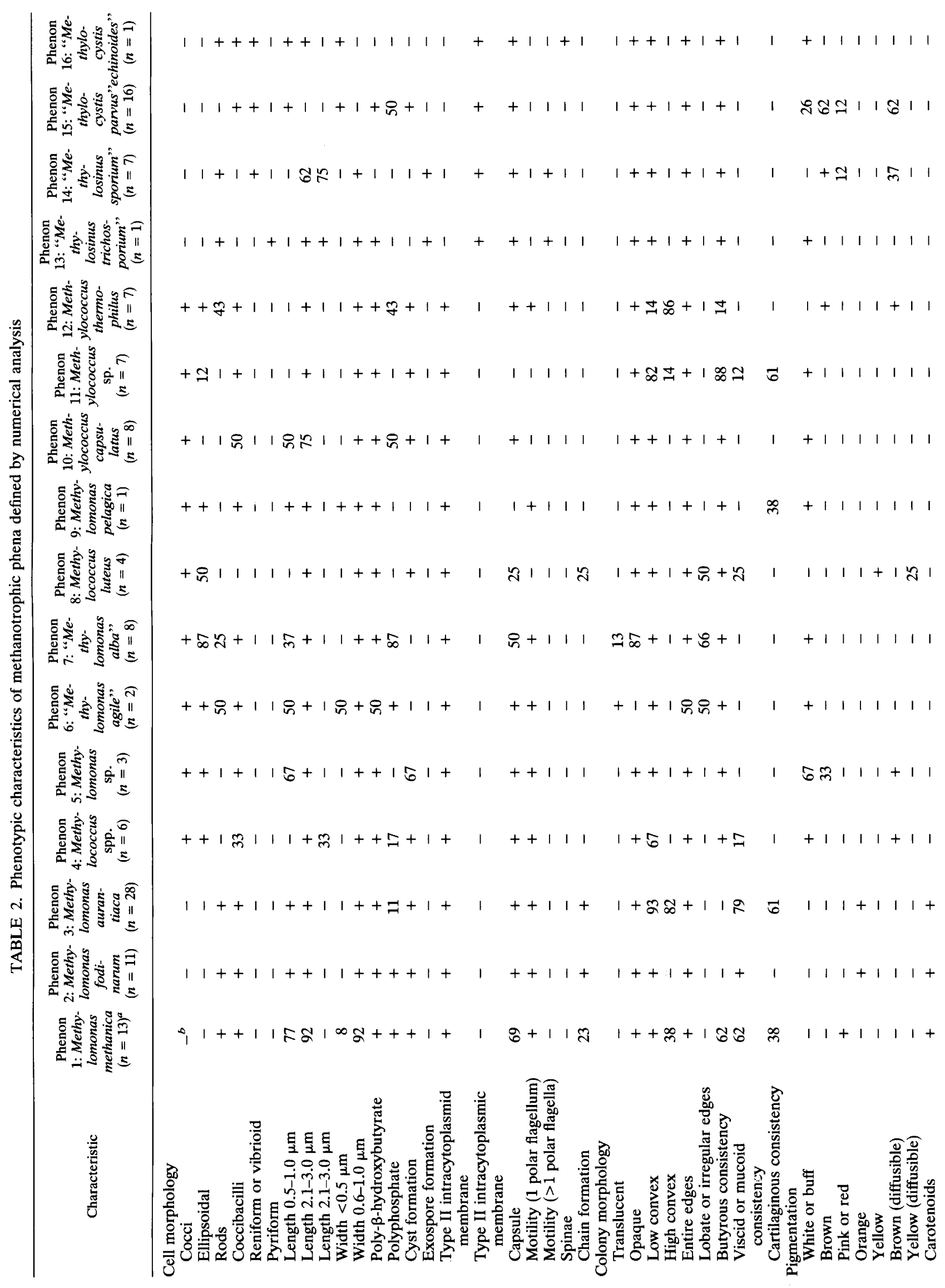




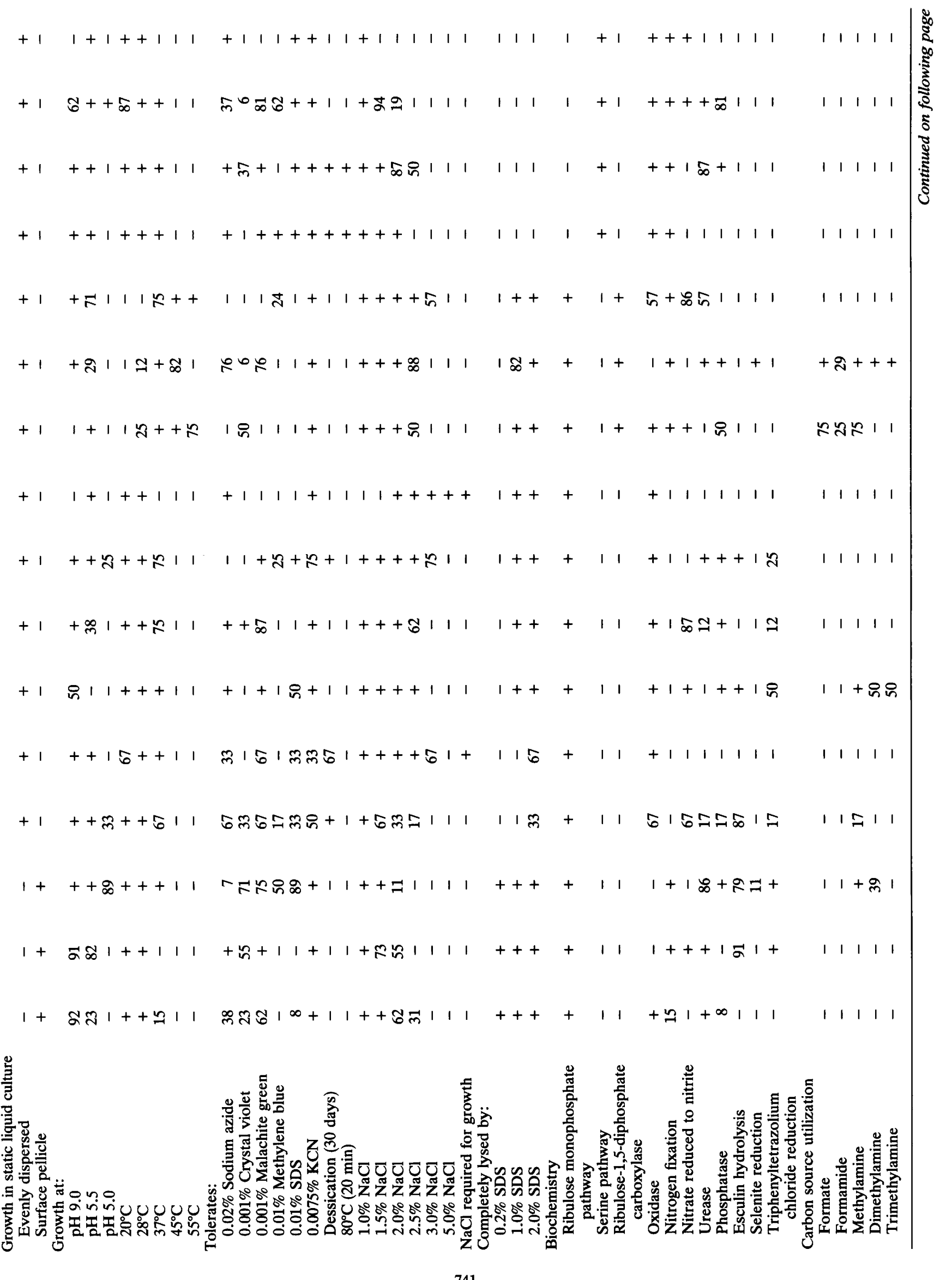




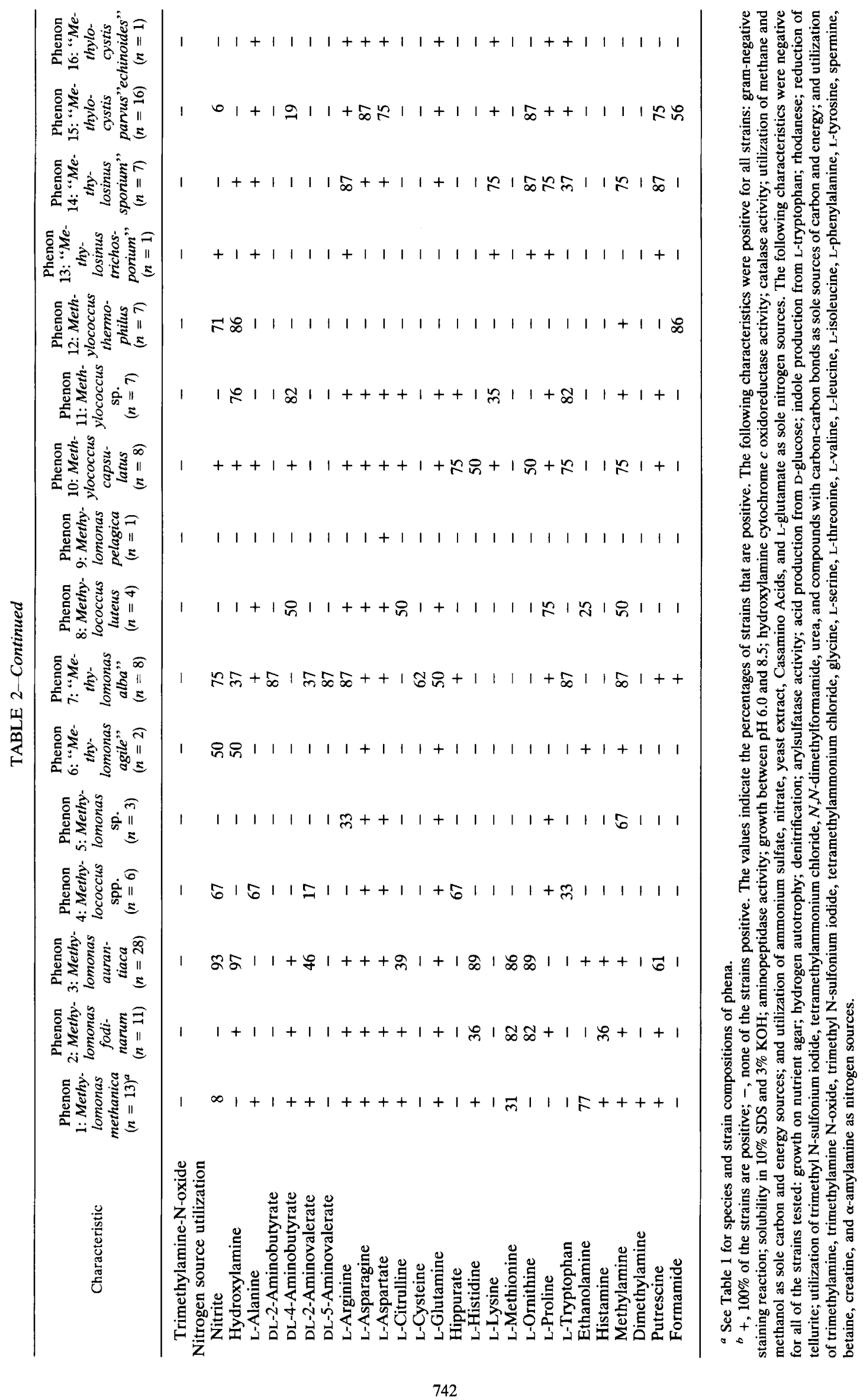


and Methylomonas pelagica, respectively. The first two of these species were found to be relatively similar phenotypically, clustering together at an $S_{J}$ value of $\geq 67 \%$ and differing primarily in their carbon and nitrogen source utilization spectra (Table 2). On the other hand, Methylomonas pelagica (phenon 9) required seawater for growth and was substantially more biochemically and nutritionally inert (Table 2).

The final broad group (phena 10 to 12) making up the group I methanotrophs included spherical and coccibacillary cells which produced desiccation-sensitive cysts. These strains were moderately thermophilic, with optimal growth temperatures ranging from 40 to $55^{\circ} \mathrm{C}$. Phenon 10 contained various strains of Methylococcus capsulatus, while phenon 11, which clustered with phenon 10 at an $S_{J}$ value of $\geq 67 \%$, contained 17 environmental isolates isolated from creek, river, and marsh mud, as well as from soil (Table 1). Interestingly, phenon 11 appeared to represent a distinct taxon of methanotrophic bacteria allied to but phenotypically distinct from Methylococcus capsulatus. This conclusion was supported by the significant phenotypic coherence observed among the strains in phenon $11\left(S_{J}\right.$, $\geq 87 \%$ ). Phena 10 and 11 were the most versatile nutritionally of all the methanotrophs studied, and they could be readily distinguished on the basis of the results of biochemical and carbon and nitrogen source tests (Table 2). Clustering with phena 10 and 11 at an $S_{J}$ value of $\geq 54 \%$, phenon 12 included the species Methylococcus thermophilus and "Methylomonas gracilis." All of the phenon 12 strains, which clustered together at an $S_{J}$ value of $\geq 80 \%$, were brown pigmented with a brown diffusible pigment produced when the organisms were first isolated. This pigment was often lost rapidly during the purification process. Morphologically and biochemically, the phenon 12 strains appeared to be similar to the phenon 10 and 11 strains except that the phenon 12 strains were motile by means of a single polar flagellum and were comparatively nutritionally inert (Table 2).

The group II methanotrophs clustered as one large group at a similarity level $\left(S_{J}\right)$ of $\geq 53 \%$. Phenon 13 strain "Methylosinus trichosporium" ACM 3311 and phenon 14 strains ("Methylosinus sporium" ACM 3306 and related environmental strains) clustered at a similarity value $\left(S_{J}\right)$ of $\geq 65 \%$ on the dendrogram (Fig. 1). All "Methylosinus" strains budded off exospores (57) and were motile by means of a tuft of flagella inserted at one pole. "Methylosinus trichosporium" ACM 3311 could be differentiated from "Methylosinus sporium" strains, which grouped together in phenon 12 at an $S_{J}$ value of $\geq 93 \%$, by its pyriform rather than vibrioid morphology, by its lack of a brown diffusible pigment or red pigment, by its lack of urease and alkaline phosphatase activities, and by various differences in nitrogen source usage (Table 2). Phenon 15 included "Methylocystis parvus" ACM 3309, Methylocystis minimus" ACM 3497 , and 14 environmental isolates clustering together at an $S_{J}$ value of $\geq 76 \%$. Phenon 15 was related to "Methylocystis echinoides" ACM 3495 (phenon 16) at an $S_{J}$ value of $\geq 66 \%$. The "Methylocystis" strains had the following properties: vibrioid or reniform cells that were small ( 0.5 to 1.0 by 0.5 to $0.7 \mu \mathrm{m}$ ), lacked motility, and formed lipid cysts (55). "Methylocystis echinoides" (22) strain ACM 3495 could be distinguished from phenon 13 strains by its production of unusual surface protuberances (or spinae) (18), by its lack of pigmentation, by its inability to grow at $37^{\circ} \mathrm{C}$ or below $\mathrm{pH}$ 6.0 , and by its lack of urease or phosphatase production (Table 2).
DNA-DNA hybridization. Levels of DNA homology were determined between representatives of each of the phena identified in the numerical analysis (Table 3). Levels of genetic relatedness between the species in phena 1 through 3 have been reported previously (6). "Methylomonas rubra", ACM 3303 was $100 \%$ related to Methylomonas methanica. Methylomonas fodinarum and Methylomonas aurantiaca were also closely related, exhibiting DNA homology levels of $45 \% \pm 15 \%$; however, these organisms exhibited no significant level of homology with any of the Methylomonas methanica strains tested. High levels of DNA homology were detected between strains clustered in phenon 4 and between strains clustered in phenon 8 . The phenon 4 species "Methylococcus ucrainicus," Methylococcus vinelandii, and Methylococcus whittenburyi exhibited DNA homology levels of 54 to $93 \%$, while the phenon 8 species Methylococcus bovis and Methylococcus luteus exhibited a level of homology of $98 \%$. The strains in phena 5 through 7 and 9 were found to be genetically distinct (Table 3). Methylococcus capsulatus (phenon 10) exhibited significant levels of DNA relatedness ( 40 to $43 \%$ ) to the strains in phenon 11 . The phenon 11 strains formed a genetically homologous group, with five test strains exhibiting levels of homology of 63 to $103 \%$ with reference culture JB140 (Table 3). Methylococcus thermophilus ACM $3585^{\mathrm{T}}$ exhibited $68 \%$ DNA homology with the phenotypically related species "Methylomonas gracilis" (both members of phenon 12); however, no significant level of homology was detected between these species and strains in phena 10 and 11 . The group II methanotroph phena (phena 13 through 16) were genetically distinct (Table 4).

PLFAs. By using data from this study and other methanotroph PLFA studies $(3,5,24,44)$ it was possible to divide the group I methanotrophs into six groups on the basis of PLFA profiles, while the group II methanotrophs formed a single group (Table 5). The first profile was found in Methylomonas methanica, Methylomonas fodinarum, and Methylomonas aurantiaca (phena 1 through 3); the dominant

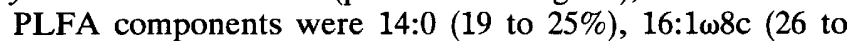
$41 \%$ ), and $16: 1 \omega 5 \mathrm{t}$ ( 8 to $15 \%$ ). The second profile was found in Methylococcus species which produced desiccation-resistant cysts (e.g., phena 4, 5, and 8); these species contained mainly $16: 1 \omega 7 \mathrm{c}(57 \%)$. The third profile was found in "Methylomonas agile" (phenon 6), "Methylomonas alba" (phenon 7), and Methylomonas pelagica (phenon 9), and the major PLFA components found were $16: 1 \omega 8 \mathrm{c}(12$ to $19 \%)$, $16: 1 \omega 7 \mathrm{c}$ (14 to $20 \%), 16: 1 \omega 6 \mathrm{c}$ (6 to $14 \%$ ), $16: 1 \omega 5$ t (6 to $28 \%$ ), and 16:0 (11 to $18 \%)$. Methylococcus capsulatus strains (phenon 10) contained primarily $16: 0$ (33 to $56 \%)$; significant levels of $16: 1 \omega 7 \mathrm{c}(11$ to $23 \%$ ) and $16: 1 \omega 6 \mathrm{c}$ (4 to $12 \%$ ) were also present. The PLFA profile of phenon 11 strains was found to be quite similar to that of Methylococcus capsulatus; however, the levels of $18: 1 \omega 7 \mathrm{c}(9$ to $15 \%)$ and cy19:0 (8 to $16 \%$ ) were significantly greater (Table 5). The PLFA profiles of Methylococcus thermophilus and "Methylomonas gracilis" were also somewhat similar to the profiles of the phenon 10 and 11 strains examined; however, the 16:1 isomers were completely dominated by $16: 1 \omega 7 \mathrm{c}(17$ to $46 \%)$, which in most of the strains was present at nearly the same level as 16:0 (40 to $47 \%$ ). The group II methanotroph PLFA profile was characterized by its high content of the unusual PLFA $18: 1 \omega 8 \mathrm{c}$ (53 to $74 \%$ ), while $18: 1 \omega 7 \mathrm{c}$ (15 to $38 \%$ ) was also present at significant levels. 


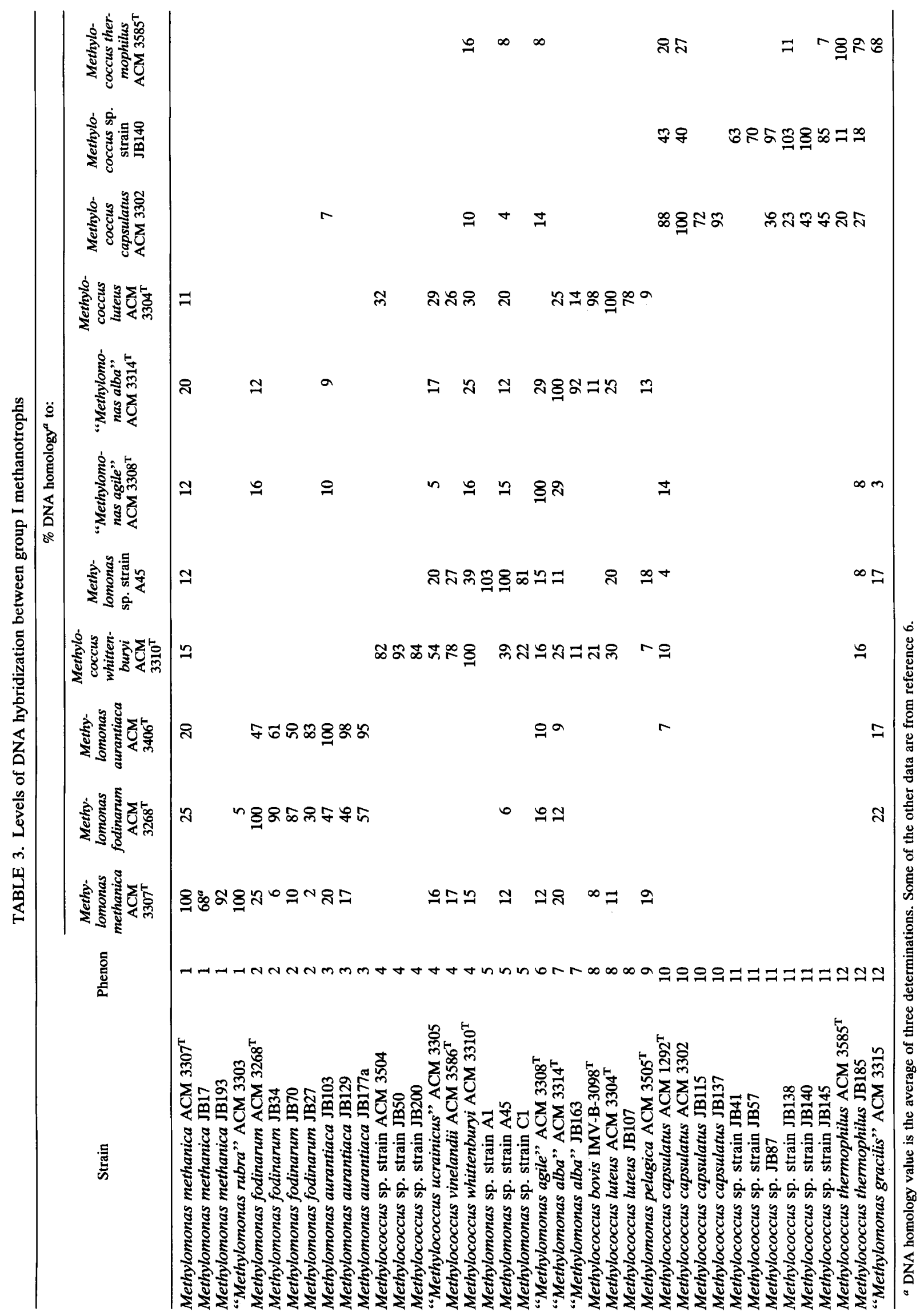


TABLE 4. Levels of DNA hybridization between group II methanotrophs

\begin{tabular}{|c|c|c|c|c|c|}
\hline \multirow[b]{2}{*}{ Strain } & \multirow[b]{2}{*}{ Phenon } & \multicolumn{4}{|c|}{$\%$ DNA homology ${ }^{a}$ to: } \\
\hline & & $\begin{array}{l}\text { "Methylosinus } \\
\text { trichosporium" ACM } \\
3311 \text { (phenon 13) }\end{array}$ & $\begin{array}{c}\text { "Methylosinus } \\
\text { sporium" ACM 3306 } \\
\text { (phenon 14) }\end{array}$ & $\begin{array}{c}\text { “Methylocystis } \\
\text { parvus" ACM } 3309 \\
\text { (phenon 15) }\end{array}$ & $\begin{array}{c}\text { "Methylocystis } \\
\text { echinoides" ACM } 3495 \\
\text { (phenon 16) }\end{array}$ \\
\hline "Methylosinus trichosporium" АCM $3311^{\mathrm{T}}$ & 13 & 100 & 21 & 19 & 9 \\
\hline “Methylosinus sporium" ACM $3306^{\mathrm{T}}$ & 14 & 21 & 100 & 16 & 21 \\
\hline JB153 & 14 & & 90 & & \\
\hline JB206 & 14 & 10 & 71 & 12 & \\
\hline “Methylocystis minimus" ACM 3497 & 15 & 16 & & 68 & \\
\hline "Methylocystis parvus" ACM $3309^{\mathrm{T}}$ & 15 & 8 & 7 & 100 & 20 \\
\hline JB33 & 15 & & 3 & 96 & \\
\hline JB170 & 15 & & 12 & 101 & \\
\hline JB190 & 15 & & & 78 & \\
\hline JB196 & 15 & & 14 & 82 & \\
\hline "Methylocystis echinoides" ACM $3495^{\mathrm{T}}$ & 16 & 9 & & 20 & 100 \\
\hline
\end{tabular}

${ }^{a}$ DNA homology value is the average of three determinations.

\section{DISCUSSION}

On the basis of the results of an extensive phenotypic survey it was possible to elucidate methanotroph species and genus relationships. The results of DNA-DNA hybridization analyses indicate that several species synonyms exist in the current nomenclature. Using numerical analysis, PLFA compositions, and genomic characteristics (7) together, we were able to clarify the species and genera of the group I and II methanotrophs.

Unsuccessful attempts were made to obtain cultures of the taxonomically valid methanotrophs Methylococcus chroococcus and Methylococcus mobilis. Several other methanotrophs, all invalid and usually based on only limited descriptions from relatively cursory examinations, were also not included in this study. Most of these species have no extant cultures or designated type or reference cultures, while others are simply synonyms. The review of methanotroph systematics by Green (23) covers some of these taxa, including "Methylococcus minimus," Methylococcus mobilis, "Methylocystis methanolicus," "Methylocystis pyreformis," "Methylomonas flagellata," "Methylomonas margaritae," "Methylomonas rosaceous," "Methylomonas streptobacterium," "Methylovibrio soehngenii," and "Soehngenia thermomethanica." Other "obscure" methanotrophs include "Echinosporobacterium album" and "Polysporobacterium arenarium" (32).

Family Methylococcaceae. On the basis of 16S rRNA phylogeny, the group I methanotroph genera collectively form a relatively distinct branch in the gamma subdivision (8); in addition, the group I methanotrophs share several features which differ from the features of the group II methanotrophs. The current description of the family Methylococcaceae includes all of the methanotrophs and the genus Methylobacterium (56). It is proposed that the family Methylococcaceae should include only the group I methanotrophs, with the genus Methylococcus as the type genus. An emended description of the family Methylococcaceae is given below.

Emended description of the family Methylococcaceae (ex Whittenbury and Krieg 1984). Cell morphology varies from rods to cocci that are 0.5 to $1.5 \mu \mathrm{m}$ in diameter and 1.0 to 3.0 $\mu \mathrm{m}$ long. Cells usually occur singly or in pairs, occasionally forming chains. Cells do not form rosettes. Gram negative. The majority of the species produce a dormant resting stage that appears as a cyst similar to the cysts which occur in members of the genus Azotobacter. Cysts may be desiccation resistant or sensitive. If the cells are motile, they possess a single polar flagellum. Catalase is produced. Strictly aerobic chemoheterotrophs. Obligate utilizers of $\mathrm{C}_{1}$ compounds (primarily methane and methanol) for carbon and energy. A few species can utilize methylated amines, formate, or formamide. Compounds with carbon-carbon bonds are not utilized. $\mathrm{C}_{1}$ compounds are incorporated via the ribulose monophosphate pathway. The tricarboxylic acid pathway is usually incomplete, lacking 2-oxoglutarate dehydrogenase. The dissimilatory methane oxidation pathway is associated with type I intracytoplasmic membranes which appear as stacks of vesicular discs. No growth occurs on complex organic media. No growth factors are required. Nitrogen is fixed by an oxygen-sensitive nitrogenase (not present in Methylobacter strains). Denitrification does not occur. Ammonia is oxidized to nitrite nonspecifically via methane monooxygenase and hydroxylamine cytochrome $c$ oxidoreductase. The $\mathrm{G}+\mathrm{C}$ content ranges from 49 to 66 mol\% (point of temperature inflection, $T_{i}$ ). The genome molecular weight varies from $1.5 \times 10^{9}$ to $3.0 \times 10^{9}$. Most fatty acids have a carbon chain length of 16 and are either saturated or monounsaturated; several different 16:1 isomers are present in some species. Ubiquinone 8 or its 18 -methylenated version (MQ-8) are the predominant lipoquinones present (12). The member genera include Methylomonas, Methylobacter, and Methylococcus, which form a cluster within the $\gamma$ subdivision of the Proteobacteria and are collectively referred to as the group I methanotrophs. The type genus is the genus Methylococcus.

Genus Methylomonas. The first group I methanotroph species cluster consists of Methylomonas methanica, Methylomonas fodinarum, and Methylomonas aurantiaca. A numerical analysis based both on $S_{J}$ values (Fig. 1) and simple matching coefficients $(6)$ showed that these species are distinct from other group I methanotrophs. PLFA composition was highly consistent among the species (Table 5) (5). The genomic physicochemical characteristics, including $\mathrm{G}+\mathrm{C}$ values $(51$ to $59 \mathrm{~mol} \%)$, genome molecular weights $(1.8$ $\times 10^{9}$ to $\left.2.3 \times 10^{9}\right)$, and DNA melting transition widths (10.5 to $12.0 \mathrm{~mol} \% \mathrm{G}+\mathrm{C}$ ), also indicate that these species are similar (7). The 16S rRNA sequences indicate that Methylomonas methanica forms a branch in the $\gamma$ subdivision of the Proteobacteria quite distinct from Methylococcus capsulatus $(8,9,52)$. It is proposed that the species Methylomonas methanica, Methylomonas aurantiaca, and Methylomonas fodinarum are the true members of the genus Methylomonas. These species are differentiated in Table 6, 
TABLE 5. PLFA profiles of group I and II methanotrophs

\begin{tabular}{|c|c|c|c|c|c|c|c|}
\hline \multirow[b]{2}{*}{ PLFA } & \multicolumn{7}{|c|}{$\%$ in $^{a}:$} \\
\hline & $\begin{array}{l}\text { Methylomonas } \\
\text { spp. (phena } 1 \\
\text { through } 3 ; \\
n=4)^{b}\end{array}$ & $\begin{array}{l}\text { Methylococcus } \\
\text { spp. (phena 4, } \\
\text { and } 8 ; n=3)^{c}\end{array}$ & $\begin{array}{c}\text { Methylomonas } \\
\text { spp. (phena } 6 \text {, } \\
7 \text {, and } 9 \\
n=2)^{d}\end{array}$ & $\begin{array}{l}\text { Methylococcus } \\
\text { capsulatus } \\
\text { (phenon } 10 \\
n=4)^{e}\end{array}$ & $\begin{array}{l}\text { Methylococcus } \\
\text { sp. (phenon } \\
11 ; n=2)^{f}\end{array}$ & $\begin{array}{l}\text { Methylococcus } \\
\text { thermophilus } \\
\text { (phenon 12; } \\
n=3)^{8}\end{array}$ & $\begin{array}{l}\text { "Methylosinus" and } \\
\text { "Methylocystis" } \\
\text { spp. (phena 13 } \\
\text { through 16; } \\
n=30)^{h}\end{array}$ \\
\hline i14:0 & $0-0.1$ & & & & & & $0-0.1$ \\
\hline $14: 1 \omega 7 \mathrm{c}$ & $0-0.2$ & & & & & & \\
\hline $14: 0$ & $18.9-24.6$ & 7.4-9.7 & $0.7-1.8$ & $0.8-6.2$ & $1.1-1.8$ & $1.5-1.9$ & $0-\operatorname{tr}$ \\
\hline i15:0 & $0-2.5$ & $0-0.4$ & $0-7.3$ & $0-0.1$ & $0-5.0$ & $0-1.3$ & $0-0.9$ \\
\hline a15:0 & $0-2.4$ & & & 0 -tr & $0-1.0$ & $0-0.1$ & $0-3.5$ \\
\hline $15: 1 \omega 6 c$ & & & & & & 0.4 & \\
\hline 15:0 & $0-1.2$ & $0-4.2$ & & $0-1.6$ & 0.5 & $0.4-12.7$ & $0-0.7$ \\
\hline i16:0 & $0-0.2$ & & & $0-0.3$ & $0-0.6$ & $0-0.2$ & $0-1.4$ \\
\hline $16: 1 \omega 9 c$ & $0-\operatorname{tr}$ & & & & $0-0.1$ & & $0-0.1$ \\
\hline $16: 1 \omega 8 c$ & $18.7-41.3$ & & $12.1-19.0$ & & $0-6.8$ & & \\
\hline $16: 1 \omega 7 \mathrm{c}$ & $7.7-15.3$ & $56.8-57.4$ & $14.1-19.9$ & $10.6-23.1$ & $10.4-26.3$ & $17.2-45.9$ & $0.3-14.2$ \\
\hline $16: 1 \omega 7 \mathrm{t}$ & & & & & & $0-2.2$ & 0 -tr \\
\hline $16: 1 \omega 6 c$ & $4.5-13.3$ & $4.4-4.9$ & $5.9-14.4$ & $3.9-12.3$ & $1.0-10.4$ & $0-4.9$ & $0-0.3$ \\
\hline $16: 1 \omega 5 \mathrm{c}$ & $1.9-6.3$ & $5.5-7.8$ & $5.6-7.4$ & $3.2-9.0$ & $1.0-4.7$ & $0-3.2$ & $0-0.2$ \\
\hline $16: 1 \omega 5 t$ & $7.9-16.6$ & $10.6-10.8$ & $5.6-28.2$ & $1.8-6.0$ & $0-8.7$ & & \\
\hline $16: 1 \omega 4 t$ & & & & $0-0.4$ & & & \\
\hline cy16:0 & & & & & & $0-1.0$ & \\
\hline $16: 0$ & $4.3-8.7$ & $8.2-8.4$ & $11.3-18.1$ & $33.5-56.0$ & $22.5-22.9$ & $39.7-47.0$ & $0.7-5.1$ \\
\hline $\mathrm{i} 17: 1 \omega 7 \mathrm{c}$ & $0-\operatorname{tr}$ & & & & & & \\
\hline i17:0 & $0-0.1$ & & & & & $0-0.2$ & $0-0.3$ \\
\hline a17:0 & & & & & & & $0-0.6$ \\
\hline $17: 1 \omega 8 \mathrm{c}$ & & & & $0-\operatorname{tr}$ & & $0-0.4$ & $0-0.2$ \\
\hline $17: 1 \omega 7 \mathrm{c}$ & $0-0.7$ & & & $0-1.8$ & $0-1.8$ & $0-1.1$ & $0-0.7$ \\
\hline $17: 1 \omega 7 t$ & $0-0.3$ & & & $0-2.3$ & & & \\
\hline $17: 1 \omega 6 c$ & & & & & & & $0-0.1$ \\
\hline cy17:0 & $0-2.1$ & & & $0-14.0$ & $0-5.9$ & $0-15.1$ & $0-1.0$ \\
\hline $17: 0$ & & & $0-0.1$ & $0-\operatorname{tr}$ & $0-0.2$ & $0-1.4$ & $0-0.4$ \\
\hline cy18:0 & & & & & & & $0-6.5$ \\
\hline $18: 2 \omega 6$ & & & & & $0-3.2$ & & $0-2.9$ \\
\hline $18: 1 \omega 13 c$ & & & & & & & $0-4.9$ \\
\hline $18: 1 \omega 9 c$ & $0-0.2$ & & & $0-2.9$ & $0-11.2$ & & $0-0.4$ \\
\hline $18: 1 \omega 8 c$ & & & & & & & $52.9-73.6$ \\
\hline $18: 1 \omega 7 \mathrm{c}$ & $0.2-2.5$ & $0.5-3.1$ & $0-26.5$ & $0-6.5$ & $9.1-14.7$ & tr-3.4 & $14.8-37.7$ \\
\hline $18: 1 \omega 7 \mathrm{t}$ & & & & & $0-0.5$ & & $0-4.6$ \\
\hline $18: 1 \omega 5 c$ & $0-0.2$ & & & & & & $0-0.2$ \\
\hline 18:0 & $0-0.1$ & & $0-2.8$ & $0-2.1$ & $1.6-2.7$ & $0.1-0.7$ & $0-5.0$ \\
\hline br19:1 & $0-0.5$ & & & & & & $0-0.2$ \\
\hline cy19:0 & $0.2-0.4$ & & & $0.6-1.8$ & $7.6-12.3$ & $0-2.9$ & $0-0.4$ \\
\hline
\end{tabular}

a See Table 1 for strain designations. Data are from reference 5 unless otherwise specified.

b Methylomonas methanica ACM $3307^{\mathrm{T}}$ (phenon 1), "Methylomonas rubra" ACM 3303 (phenon 1) (this study), Methylomonas fodinarum ACM $3268^{\mathrm{T}}$ (phenon 2), and Methylomonas aurantiaca ACM $3406^{\mathrm{T}}$ (phenon 3).

${ }^{c}$ Methylococcus whittenburyi ACM $3310^{\mathbf{T}}$ (phenon 4), Methylomonas sp. strain A45 (phenon 5) (this study), and Methylococcus luteus ACM $3304^{T}$ (phenon 8).

d "Methylomona agile" ACM 3308' (phenon 6), "Methylomonas alba" ACM 3314 (phenon 7) (this study), and Methylomonas pelagica ACM 3505" (phenon 9) (this study).

Methylococcus capsulatus ACM 3302 (this study), JB115 (this study), and JB137 (this study). PLFA data for ACM $1292^{\mathrm{T}}$ which were obtained from reference 2 are also included.

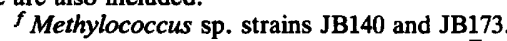

g Methylococcus thermophilus ACM 3585 (this study), "Methylomonas gracilis" ACM 3315, and strain JB187 (this study).

h "Methylosinus trichosporium" ACM 3311 (phenon 13), "Methylosinus sporium" ACM 3306" (phenon 14), "Methylosinus" sp. strain IMV-B 3006 (this study), "Methylocystis parvus" ACM 3309T, "Methylocystis minimus" (phenon 15), and "Methylocystis echinoides" ACM 3495 (phenon 16). Additional PLFA data for 24 strains isolated from a groundwater aquifer and identified as members of either the genus "Methylosinus" or the genus "Methylocystis" were obtained from reference 4 .

while the genus Methylomonas is differentiated from other methanotrophic genera in Table 7. An extended description of the genus Methylomonas is given below.

Extended description of the genus Methylomonas (Whittenbury and Krieg 1984). Cells are rodlike to coccobacillary and 0.5 to $1.0 \mu \mathrm{m}$ wide by 1.0 to $2.0 \mu \mathrm{m}$ long. Motile by means of a single polar flagellum. Produces poly- $\beta$-hydroxybutyrate inclusions and desiccation-sensitive Azotobacter type cysts. Most strains produce capsules. Forms a surface pellicle when grown in static liquid culture. Pink and orange carotenoid pigments are produced. Optimum growth occurs at temperatures between 25 and $35^{\circ} \mathrm{C}$; no growth occurs at temperatures above $40^{\circ} \mathrm{C}$. Growth occurs between $\mathrm{pH} 5.0$ and 9.0; optimum growth occurs at $\mathrm{pH} 6.5$ to 7.0. $\mathrm{NaCl}$ is not required for growth. $\mathrm{NaCl}$ inhibits growth at a concentration of $1.5 \%(\mathrm{wt} / \mathrm{vol})$. Cells are susceptible to lysis by $0.2 \%$ (wt/vol) SDS. The Benson-Calvin cycle is not present. Urease is produced. The major PLFAs are 14:0 and 16:1w8c. 
The major ubiquinone is 18-methylene-ubiquinone 8 (only determined for Methylomonas methanica) (12). The $\mathrm{G}+\mathrm{C}$ content is 51 to $59 \mathrm{~mol} \%\left(T_{i}\right)$. The type species is Methylomonas methanica (56). Other species include Methylomonas fodinarum and Methylomonas aurantiaca (6).

Misclassified Methylomonas species. The species "Methylomonas agile," "Methylomonas alba," and Methylomonas pelagica have been compared with Methylomonas methanica by using only a relatively limited array of characteristics $(42-45,57)$. In this study the results of a numerical analysis and DNA-DNA hybridization indicated that these species are distinct from each other and from other group I methanotrophs at the species level. These species exhibit certain obvious phenotypic differences with Methylomonas methanica, Methylomonas fodinarum, and Methylomonas aurantiaca, including the absence of pigmentation and cyst formation. In addition, these species have different PLFA profiles; they lack significant levels of 14:0 and have a different distribution of 16:1 isomers (Table 5). The results of molecular studies, including genome characteristics (7) and the results of $5 \mathrm{~S}$ rRNA $(10)$ and $16 \mathrm{~S}$ rRNA $(8,9)$ sequence analyses, suggest that these species are more closely related to the mesophilic, desiccation-resistant cyst-forming Methylococcus species. However, some ambiguities exist in these data. Genomic characteristics place "Methylomonas agile" ACM 3308 with the carotenoid-containing Methylomonas species, and this organism seems to be quite different from its close phenotypic ally "Methylomonas alba" (7). The similarity of "Methylomonas agile" and "Methylomonas alba" in terms of their phenotypes and PLFA profiles suggests that these organisms are generically related; recently, phylogenetic data based on $16 \mathrm{~S}$ ribosomal DNA sequences confirmed that there is a close relationship between these species, as well as between these species and Methylomonas pelagica and the desiccation-resistant cystforming mesophilic Methylococcus species (9).

In the case of "Methylomonas gracilis" ACM 3315, DNA-DNA hybridization analysis data indicated that this name is was a synonym of Methylococcus thermophilus. This conclusion is also supported by the results of the numerical analysis, which placed strain ACM 3315 in phenon 12 along with Methylococcus thermophilus. The PLFA profile (Table 5) and the genomic characteristics (7) of "Methylomonas gracilis" ACM 3315 are also very similar to those of Methylococcus thermophilus ACM $3585^{\mathrm{T}}$.

Methylococcus species. The results of systematic studies of methanotroph fatty acids $(5,24)$, protein electrophoretic patterns (21), DNA base compositions $(7,36)$, genome molecular weights, and DNA melting transition widths (7) clearly demonstrate the heterogeneity present in the genus Methylococcus. These results suggest that the genus Methylococcus consists of two groups of species, each of which represents a different genus.

The high-G+C-content, moderately thermophilic Methylococcus species make up a distinct group I methanotroph species cluster (phena 10 through 12) (Fig. 1). This cluster includes the species Methylococcus capsulatus (phenon 10) and a phenotypically and genotypically allied cluster of strains forming phenon 11. Phenon 11 strains, however, possessed several phenotypic traits differentiating them from Methylococcus capsulatus (Table 2). Even though substantial levels of DNA homology $(37 \% \pm 8 \%)$ seem to exist between the strains of these phena, the homology values are well below the level recommended for intraspecies relatedness. Phenon 12 includes the species Methylococcus thermophilus, which is phenotypically and genotypically distinct

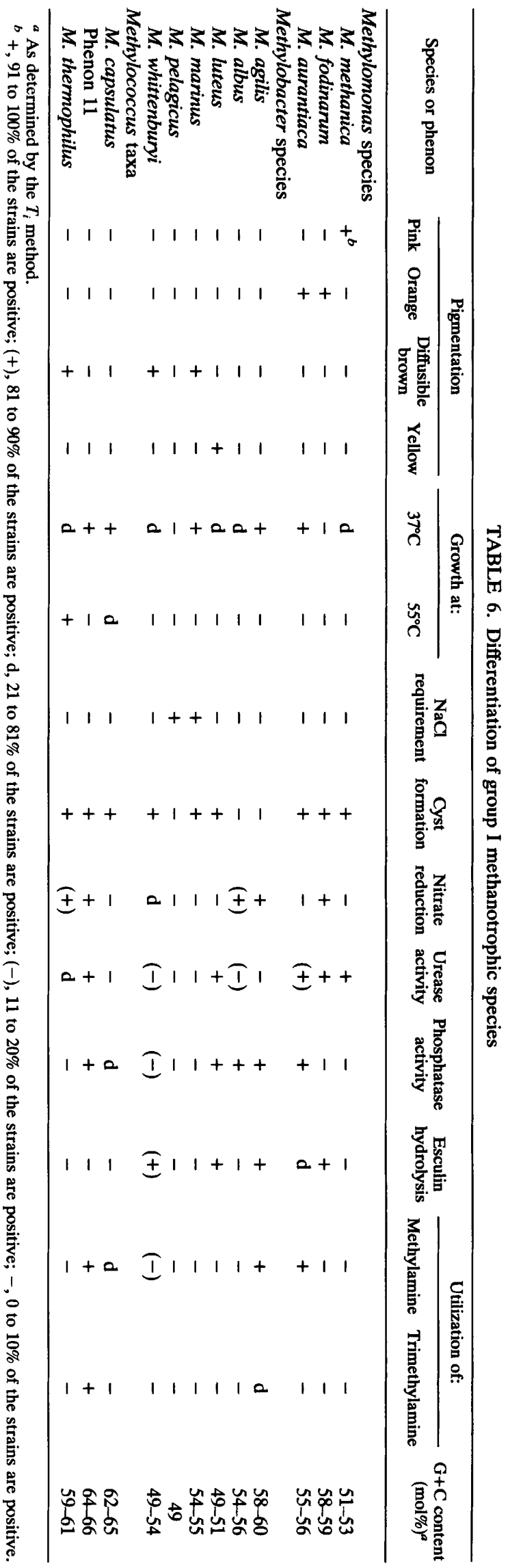


TABLE 7. Characteristics that differentiate methanotroph genera

\begin{tabular}{|c|c|c|c|c|c|}
\hline Characteristic & Methylomonas & Methylobacter & Methylococcus & Methylosinus & Methylocystis \\
\hline \multicolumn{6}{|l|}{ Cell morphology } \\
\hline Rods & $t^{a}$ & D & - & _ & - \\
\hline Cocci or ellipsoid & - & $\mathrm{D}$ & + & - & + \\
\hline Curved & - & - & - & $\mathrm{D}$ & + \\
\hline Pyriform & - & - & - & $\mathrm{D}$ & - \\
\hline Type I intracytoplasmic membranes & + & + & + & - & - \\
\hline Type II intracytoplasmic membranes & - & - & - & + & + \\
\hline Motility & + & D & D & + & - \\
\hline Carotenoids produced & + & - & - & - & - \\
\hline \multicolumn{6}{|l|}{ Cyst formation } \\
\hline Desiccation sensitive & + & - & + & - & + \\
\hline Desiccation resistant & - & D & - & _ & - \\
\hline Exospore (bud) formation & - & - & - & + & - \\
\hline Lysed by $0.2 \%$ (wt/vol) SDS & + & _ & - & - & _ \\
\hline Growth at $45^{\circ} \mathrm{C}$ & - & - & + & - & - \\
\hline Ribulose monophosphate pathway ${ }^{b}$ & + & + & + & _ & - \\
\hline Serine pathway ${ }^{b}$ & - & - & - & + & + \\
\hline Ribulose-1,5-diphosphate carboxylase & - & - & + & - & - \\
\hline Nitrogen fixation & D & - & + & + & + \\
\hline Major PLFA component(s) & $14: 0,16: 1 \omega 8 c$ & $16: 1 \omega 7 \mathrm{c}$ or $16: 1 \omega 5 t$ & $16: 0$ and/or $16: 1 \omega 7 \mathrm{c}$ & $18: 1 \omega 8 \mathrm{c}$ & $18: 1 \omega 8 \mathrm{c}$ \\
\hline Quinone $^{c}$ & MQ-8 & Q-8 & MQ-8 & Q-8 & Q-8 \\
\hline $\begin{array}{l}\text { Proteobacterial subdivision } \\
\mathrm{G}+\mathrm{C} \text { content }(\mathrm{mol} \%)^{d}\end{array}$ & $\underset{51-59}{\gamma}$ & $\begin{array}{c}\gamma \\
49-60\end{array}$ & $\begin{array}{c}\gamma \\
59-66\end{array}$ & $\begin{array}{c}\alpha \\
63-67\end{array}$ & $\begin{array}{c}\alpha \\
62-67\end{array}$ \\
\hline
\end{tabular}

$a+, 91$ to $100 \%$ of the strains are positive; D, variation among species;,- 0 to $10 \%$ of the strains are positive.

${ }^{b}$ Predominant pathway.

${ }^{c}$ Data from reference 12 . MQ-8, 18-methyleneubiquinone 8; Q-8, ubiquinone 8.

${ }^{d}$ As determined by the $T_{i}$ method.

from phena 10 and 11 . These three phena exhibit high levels of similarity on the basis of genomic characteristics (7) and PLFA profiles (Table 5). As phena 10 through 12 represent a distinct group separate from other group I methanotrophs, it is proposed that these strains are true members of the genus Methylococcus. The species include Methylococcus capsulatus (type species) and Methylococcus thermophilus. Severe problems were encountered in maintaining viable cultures of the phenon 11 strains, and to date no representative strain is available. Thus, no species description can be proposed for phenon 11 strains in this paper. Methylococcus capsulatus, Methylococcus thermophilus, and the phenon 11 strains are phenotypically differentiated in Table 6, while the genus Methylococcus is differentiated from other methanotrophic genera in Table 7. An emended description of the genus Methylococcus is given below.

Emended description of the genus Methylococcus (Foster and Davis 1966). Cells are cocci, coccobacilli, or occasionally short rods, are 0.8 to $1.5 \mu \mathrm{m}$ wide, 1.0 to $1.5 \mu \mathrm{m}$ long, and occur singly or in pairs. When motile, the cells possess a single polar flagellum. Produces Azotobacter type cysts which do not confer desiccation resistance. Contains a partially functional Benson-Calvin cycle which allows incorporation of carbon dioxide for cellular carbon in the presence of methane, but no autotrophic growth occurs in the absence of methane. Fixes atmospheric nitrogen via an oxygen-sensitive nitrogenase. Not susceptible to lysis by $0.2 \%$ (wt/vol) SDS. Moderate thermophiles with an optimal temperature for growth between 37 and $50^{\circ} \mathrm{C}$. The major PLFAs are $16: 0$ and $16: 1 \omega 7 \mathrm{c}$. The major ubiquinone is 18-methyleneubiquinone $8(12)$. The $\mathrm{G}+\mathrm{C}$ content is 59 to 66 mol\%. The type species is Methylococcus capsulatus, which was originally described by Foster and Davis (20). The other species belonging to this genus is Methylococcus thermophilus, which was described by Malashenko et al. (35).

Misclassified Methylococcus species. Methylococcus taxa that produce well-defined desiccation-resistant cysts (55) include the species Methylococcus bovis, Methylococcus luteus, "Methylococcus ucrainicus," Methylococcus vinelandii, and Methylococcus whittenburyi and the $\mathrm{NaCl}$-requiring strains (33) grouped in phenon 5. "Methylococcus ucrainicus," Methylococcus vinelandii, and Methylococcus whittenburyi in reality represent a single species. This conclusion is supported by the results of a numerical analysis which placed these species, as well as a strain misclassified as Methylococcus bovis (ACM 3504) and two unidentified strains (JB50 and JB200) (Table 1), in phenon 4 (level of similarity $\left[S_{J}\right], \geq 73 \%$ ). The levels of DNA homology between phenon 4 strains ranged from 54 to $93 \%$ (Table 3 ). These data correlate well with the data of Lysenko et al. (34) which indicated that the species Methylococcus chroococcus, Methylococcus vinelandii, and Methylococcus whittenburyi exhibited DNA homology levels of 70 to $90 \%$. The same circumstance exists for the phenon 8 species Methylococcus luteus and the type strain of Methylococcus bovis (IMV-B 3098), which were found to exhibit a level of DNA homology of $98 \%$ and considerable phenotypic similarity $\left(S_{J}, \geq 75 \%\right)$. Phenon 5 strains are phenotypically similar to phenon 4 species but are genotypically distinct, exhibiting levels of DNA homology of only 22 to $39 \%$ with Methylococcus whittenburyi ACM 3310 and Methylococcus luteus ACM $3304^{\mathrm{T}}$. Species clustered in phena 4,5 , and 8 have a very similar PLFA profiles (Table 5) and genome molecular weights $\left(1.5 \times 10^{9}\right.$ to $\left.2.0 \times 10^{9}\right)(7)$. The DNA base compositions of these species range from 48 to $54 \mathrm{~mol} \%$ $\mathrm{G}+\mathrm{C}(7,36)$. The results of a phylogenetic analysis based on 5S rRNA (10) and of 16S rRNA and 16S rDNA analyses (8, 9 ) indicate that these species are closely related.

"Methylomonas agile," "Methylomonas alba," and $\mathrm{Me}$ thylomonas pelagica were found to exhibit a substantial degree of phenotypic similarity to the desiccation-resistant, cyst-forming species in phena 4,5 , and 8 (Table 2 ; Fig. 1 ). 
However, because of the low number of useful phenotypic traits available to broadly classify these species, there is some difficulty in showing obvious relatedness purely on the basis of phenotypic characteristics. Although these species are genotypically distinct (Table 3 ), their PLFA compositions are quite similar (Table 5). The PLFA profiles of these species also differ from the profile of the desiccation-resistant, cyst-forming species, mainly in terms of $16: 1$ isomer distribution; however, the total contents of the various unsaturated and monounsaturated lipids (i.e., total 16:1 contents) are very similar. On the other hand, genome characteristics (7), 5S rRNA sequences (10), and 16S rRNA and ribosomal DNA sequences $(8,9)$ indicate that the organisms in phena 6,7 , and 9 that do not form cysts are related to the desiccation-resistant cyst-forming Methylococcus species in phena 4,5 , and 8 . On the basis of this evidence it is proposed that the misclassified Methylomonas and Methylococcus species should be combined in a as single genus, designated Methylobacter gen. nov. A similar proposal was put forward by Romanovskaya (42); however, the proposed genus "Methylovarius" was never validated. The members of the genus Methylobacter include Methylobacter luteus comb. nov. (the type species), Methylobacter agilis sp. nov., Methylobacter albus comb. nov., nom. rev., Methylobacter marinus sp. nov. (for the phenon 5 strains), Methylobacter pelagicus comb. nov., and Methylobacter whittenburyi comb. nov. These species are phenotypically differentiated from each other in Table 6, while the genus Methylobacter is differentiated from other methanotrophic genera in Table 7. Descriptions of Methylobacter gen. nov. and its species are given below.

Description of the genus Methylobacter gen. nov. Methylobacter (Me.thyl.o.bact'er. N.L. n. methylo, the methyl group; Gr. n. bacter, rod; N.L. masc. n. Methylobacter, methyl rod). The gram-negative cells vary from cocci to elliptical and/or fat short rods that are 0.8 to $1.5 \mu \mathrm{m}$ wide by 1.2 to $3.0 \mu \mathrm{m}$ long. When motile, cells always have a single polar flagellum. If cysts are present, they appear similar to those observed in members of the genus Azotobacter and are desiccation resistant but not heat resistant. Benson-Calvin cycle enzymes are not present. Atmospheric nitrogen is not fixed. Cells are not lysed by $0.2 \%$ (wt/vol) SDS. Growth in liquid cultures is evenly dispersed. Carotenoid pigments are not produced. Optimal growth occurs at temperatures between 20 and $37^{\circ} \mathrm{C}$; no growth occurs at temperatures over $40^{\circ} \mathrm{C}$. Grow occurs between $\mathrm{pH} 5.0$ and 9.0; optimum growth occurs at $\mathrm{pH} 6.5$ to 7.0 . The major PLFA is $16: 1 \omega 7 \mathrm{c}$ or $16: 1 \omega 5 t$, while the major ubiquinone is ubiquinone $8(12)$. The $\mathrm{G}+\mathrm{C}$ content varies from 49 to $60 \mathrm{~mol} \%$. The type species is Methylobacter luteus.

Description of Methylobacter luteus (Romanovskaya, Malashenko, and Bogachenko 1978) comb. nov. Methylobacter luteus (basonym, Methylococcus luteus; synonym, Methylococcus bovis Romanovskaya, Malashenko, and Bogachenko 1978). The characteristics are the same as the characteristics given in the genus description above, including the following traits. Cells are nonmotile. Forms desiccation-resistant $\mathbf{A z O}$ tobacter type cysts. Does not form polyphosphate inclusions. Colonies are pale to bright yellow, irregular or round, and low convex with entire or irregular edges and have a butyrous consistency. $\mathrm{NaCl}$ is not required for growth. Optimal growth occurs at $30^{\circ} \mathrm{C}$. Oxidase, urease, and phosphatase are produced. Does not reduce nitrate, selenite, tellurite, or triphenyltetrazolium chloride. Hydrolyzes esculin. Utilizes methane and methanol as sole sources of carbon and energy. Other traits are shown in Table 2. The $\mathrm{G}+\mathrm{C}$ content of the DNA is 49 to $51 \mathrm{~mol} \%\left(T_{i}\right)$. The major PLFA component is $16: 1 \omega 7 \mathrm{c}$. The type strain is NCIMB 11914 (= ACM 3304 = VKM-53B).

Description of Methylobacter agilis sp. nov. Methylobacter agilis (basonym, "Methylomonas agile"' Whittenbury, Phillips, and Wilkinson 1970) (a.gi'lis. M. L. adj. agilis, agile). The characteristics are the same as the characteristics given in the genus description above, including the following traits. Cells are motile by means of a single polar flagellum. Does not form desiccation-resistant Azotobacter type cysts. Forms polyphosphate inclusions. Colonies are translucent, white, round, and low convex with entire or lobate edges and have a butyrous consistency. $\mathrm{NaCl}$ is not required for growth. Optimal growth occurs at $30^{\circ} \mathrm{C}$. Oxidase and phosphatase are produced. Urease negative. No reduction of nitrate, selenite, or tellurite occurs. Reduces triphenyltetrazolium chloride. Esculin is hydrolyzed. Utilizes methane, methanol, and methylamine as sole sources of carbon and energy. Other traits are shown in Table 2. The $\mathrm{G}+\mathrm{C}$ content of the DNA is 58 to $60 \mathrm{~mol} \%\left(T_{i}\right)$. The major PLFA component is $16: 1 \omega 5 \mathrm{t}$. The type strain is NCIMB 11124 (= A30 = ACM $3308=$ ATCC 35068).

Description of Methylobacter albus sp. nov. Methylobacter albus (basonym, "Methylomonas albus" Whittenbury, Phillips, and Wilkinson 1970) (al'bus. M. L. adj. albus, white). The characteristics are the same as the characteristics given in the genus description above, including the following traits. Cells are motile by means of a single polar flagellum. Does not form desiccation-resistant Azotobacter type cysts. Forms polyphosphate inclusions. Colonies are white, round, and low convex with entire or lobate edges and have a butyrous consistency. $\mathrm{NaCl}$ is not required for growth. Optimal growth occurs at $30^{\circ} \mathrm{C}$. Phosphatase is produced. Negative for oxidase, urease, and esculin hydrolysis. Reduces nitrate to nitrite but does not reduce selenite, tellurite, or triphenyltetrazolium chloride. Utilizes methane and methanol as sole sources of carbon and energy. Other traits are shown in Table 2. The $\mathrm{G}+\mathrm{C}$ content of the DNA is 54 to $56 \mathrm{~mol} \%\left(T_{i}\right)$. The major PLFA component is $16: 1 \omega 5 \mathrm{t}$. The type strain is NCIMB 11123 (= VKM-BG8 = ACM 3314).

Description of Methylobacter marinus sp. nov. Methylobacter marinus (mar'i.nus. M. L. adj. marinus, from the sea). The characteristics are the same as the characteristics given in the genus description above, including the following traits. Cells are motile by means of a single polar flagellum. Forms desiccation-resistant Azotobacter type cysts. Does not form polyphosphate inclusions. Colonies are buff to brown, round, and low convex with entire edges and have a butyrous consistency. Produces a diffusible brown pigment. $\mathrm{NaCl}$ (approximately $100 \mathrm{mM}$ ) and an unknown component present in tap water are required for growth. Optimal growth occurs at $37^{\circ} \mathrm{C}$. Oxidase is produced. Urease and phosphatase negative. Does not reduce nitrate, selenite, tellurite, or triphenyltetrazolium chloride. Does not hydrolyze esculin. Utilizes methane and methanol as sole sources of carbon and energy. Other traits are shown in Table 2. The $\mathrm{G}+\mathrm{C}$ content of the DNA is 54 to $55 \mathrm{~mol} \%\left(T_{i}\right)$. The type strain is ACM 4717. This strain, originally referred to as A4, was isolated by Lidstrom (33) from seawater near a sewage outfall in California; subsequently, the strain was methanol adapted and is now referred to as strain A45.

Description of Methylobacter pelagicus (Sieburth, Johnson, Eberhardt, Sieracki, Lidstrom, and Laux 1987) comb. nov. Methylobacter pelagius (basonym, Methylomonas pelagica Sieburth, Johnson, Eberhardt, Sieracki, Lidstrom, and Laux 
TABLE 8. Phenotypic characteristics that differentiate group II methanotrophic species

\begin{tabular}{|c|c|c|c|c|}
\hline Characteristic & $\begin{array}{l}\text { Methylosinus } \\
\text { trichosporium }\end{array}$ & $\begin{array}{l}\text { Methylosinus } \\
\text { sporium }\end{array}$ & $\begin{array}{c}\text { Methylocystis } \\
\text { parvus }\end{array}$ & $\begin{array}{c}\text { Methylocystis } \\
\text { echinoides }\end{array}$ \\
\hline \multicolumn{5}{|l|}{ Cell morphology } \\
\hline Pyriform & $t^{a}$ & - & - & - \\
\hline Reniform or vibrioid & - & + & + & + \\
\hline Polyphosphate or cyst formation & - & - & + & - \\
\hline Spinae & - & - & - & + \\
\hline Growth at $37^{\circ} \mathrm{C}$ & + & + & + & - \\
\hline Urease activity & - & + & $(+)$ & - \\
\hline Phosphatase activity & - & + & $(+)$ & - \\
\hline \multicolumn{5}{|l|}{ Nitrogen source utilization } \\
\hline L-Asparagine, L-aspartate, L-glutamine & - & + & $(+)$ & + \\
\hline L-Lysine, L-ornithine, putrescine & + & $(+)$ & $(+)$ & - \\
\hline $\mathrm{G}+\mathrm{C}$ content $(\mathrm{mol} \%)$ & 63 & $65-67$ & $64-67$ & 62 \\
\hline
\end{tabular}

${ }^{a}+, 91$ to $100 \%$ of the strains are positive; $(+), 81$ to $90 \%$ of the strains are positive;,- 0 to $10 \%$ of the strains are positive.

1987). The characteristics are the same as the characteristics given in the genus description above, including the following traits. Cells are motile by means of a single polar flagellum. Does not form desiccation-resistant Azotobacter type cysts or polyphosphate inclusions. Colonies are white to buff, round, and low convex with entire edges and have a butyrous consistency. Seawater is required for growth. No growth occurs at $37^{\circ} \mathrm{C}$; optimal growth occurs at $25^{\circ} \mathrm{C}$. Oxidase is produced. Urease and phosphatase negative. Does not reduce nitrate, selenite, tellurite, or triphenyltetrazolium chloride. Does not hydrolyze esculin. Utilizes methane and methanol as sole sources of carbon and energy. Other traits are shown in Table 2. The $\mathrm{G}+\mathrm{C}$ content of the DNA is $49 \mathrm{~mol} \%\left(T_{i}\right)$. The type strain is NCIMB 2265 (= AA23).

Description of Methylobacter whittenburyi (Romanovskaya, Malashenko, and Bogachenko 1978) comb. nov. Methylobacter whittenburyi (basonym, "Methylobacter capsulatus" Whittenbury, Phillips, and Wilkinson 1970; synonym, Methylococcus vinelandii Romanovskaya, Malashenko, and Bogachenko 1978). The characteristics are the same as the characteristics given in the genus description above, including the following traits. Cells are motile by means of a single polar flagellum. Forms desiccation-resistant Azotobacter type cysts. Does not form polyphosphate inclusions. Colonies are round and low convex with entire edges and have a butyrous or mucoid consistency. Colonies are white; however after extended incubation colonies become brown, and a brown diffusible pigment is produced. $\mathrm{NaCl}$ is not required for growth. Optimal growth occurs at $30^{\circ} \mathrm{C}$. Does not produce urease or phosphatase. No reduction of selenite and tellurite occurs. Esculin is hydrolyzed. Utilizes methane and methanol as sole sources of carbon and energy. The G+C content of the DNA is 49 to $54 \mathrm{~mol} \%\left(T_{i}\right)$. The major PLFA component is $16: 1 \omega 7 \mathrm{c}$. The type strain is NCIMB $11128(=\mathrm{Y}$ = ACM 3310), which replaces lectotype strain 1521, which is not extant.

Group II methanotrophs. The Group II methanotrophs comprise two groups of species (phena 13 and 14 and phena 15 and 16) which exhibit various phenotypic (Fig. 1 and Tables 2 and 8) and genotypic differences (Table 4). "Methylosinus" and "Methylocystis" strains have also been shown to differ in their protein electrophoretic patterns (21), in serology (3), and in their genome molecular weights (7). 5S rRNA sequences $(10)$ and $16 \mathrm{~S}$ rRNA sequences $(9,52)$ have also shown that "Methylosinus" species are distinct from but still relatively closely related to "Methylocystis parvus." On the other hand, the ubiquinone contents (12), DNA base compositions, and DNA melting transition widths (7) of various group II methanotrophs have been found to be quite similar. On this basis it is proposed that Methylosinus gen. nov., nom. rev. and Methylocystis gen. nov., nom. rev. and their species should be revived from the original invalid descriptions $(43,56)$. Each genus has two member species, as follows: Methylosinus trichosporium sp. nov., nom. rev. (type species) and Methylosinus sporium sp. nov., nom. rev.; and Methylocystis parvus sp. nov., nom. rev. (type species) and Methylocystis echinoides sp. nov., nom. rev. The genus Methylocystis has potentially more member species (22); however, strains of these potential species need to analyzed by using DNA-DNA hybridization to ascertain their distinctiveness. The group II methanotroph species are differentiated phenotypically in Table 8 , while the genera are differentiated in Table 7. Descriptions of the group II methanotroph genera and species are given below.

Description of the genus Methylosinus gen. nov. (ex Romanovskaya, Malashenko, and Bogachenko 1978). Methylosinus (Me.thyl.o.si'nus. N. L. n. methylo, methyl group; L. n. sinus, bend; N. L. masc. n. Methylosinus, methyl bender). Gram-negative pyriform or vibrioid cells that are 0.5 to 1.0 $\mu \mathrm{m}$ wide by 1.5 to $3.0 \mu \mathrm{m}$ long. Forms rosettes in logarithmic growth phase. When not present in rosettes, cells are motile by means of a polar tuft of flagella. Cells primarily reproduce by budding off heat- and desiccation-resistant exospores from the nonflagellated pole. Cells are encapsulated but do not accumulate polyphosphate. Cells contain type II intracytoplasmic membranes which are aligned parallel to the cell wall. Cells are not susceptible to lysis by SDS. Grows at temperatures between 20 and $37^{\circ} \mathrm{C}$; no growth occurs at temperatures above $40^{\circ} \mathrm{C}$; the optimal growth temperature is about $30^{\circ} \mathrm{C}$. Grows between $\mathrm{pH} 5.5$ and 9.0; the optimal $\mathrm{pH}$ is 6.5 to 7.0. Organic growth factors and $\mathrm{NaCl}$ are not required for growth. Strictly aerobic chemoheterotrophs. Group II methanotroph. Obligate utilizer of $\mathrm{C}_{1}$ compounds via the serine transhydroxymethylase pathway. Compounds with carbon-carbon bonds do not serve as sole sources of carbon and energy. No growth occurs on complex organic media such as nutrient agar. Does not contain the BensonCalvin cycle for $\mathrm{CO}_{2}$ fixation but contains a complete tricarboxylic acid cycle, unlike the group I methanotrophs. Fixes atmospheric nitrogen by means of an aerotolerant nitrogenase. Produces oxidase and catalase. Unable to grow autotrophically, to denitrify, or to reduce nitrate to nitrite. Contains 18:1 $18 \mathrm{c}$ as the predominant PFLA. The major quinone is ubiquinone $8(12)$. The DNA base composition 
ranges from 63 to $67 \mathrm{~mol} \% \mathrm{G}+\mathrm{C}\left(T_{i}\right)$. Methylosinus trichosporium is the type species.

Description of Methylosinus trichosporium sp. nov. (ex Romanovskaya, Malashenko, and Bogachenko, 1978). Methylosinus trichosporium (tri.cho.spo'ri.um. G. n. trix, hair; L. n. spora, spore; N. L. n. trichosporium, hairlike spore). The characteristics are the same as the characteristics given in the genus description above, including the following traits. Cells are pear shaped (pyriform) and 0.5 to $1.5 \mu \mathrm{m}$ wide by 2.0 to $3.0 \mu \mathrm{m}$ long. The budding of exospores from the nonflagellated ends of the cells make the cells appear somewhat like fat exclamation marks. Colonies on NMS agar are opaque, have smooth surfaces, are low convex and circular with entire edges, have a butyrous consistency, and are white to buff. No diffusible pigments are produced. Urease and phosphatase are not produced. Esculin is not hydrolyzed. Selenite and triphenyltetrazolium chloride are not reduced. Methane and methanol are the only known sole carbon and energy sources. Other traits are shown in Table 2 . The $\mathrm{G}+\mathrm{C}$ content of the DNA is $63 \mathrm{~mol} \%\left(T_{i}\right)$. The type strain is NCIMB $11131(=$ OB3b $=$ ACM $3311=$ IMET $10543=$ ATCC 35070)

Description of Methylosinus sporium sp. nov. (ex Romanovskaya, Malashenko, and Bogachenko 1978). Methylosinus sporium (spo'ri.um. L. n. spora, spore; N. L. n. sporium, spore former). The characteristics are the same as the characteristics given in the genus description above, including the following traits. Cells are vibrioid to rod shaped and 0.5 to $1.0 \mu \mathrm{m}$ wide by 1.5 to $3.0 \mu \mathrm{m}$ long. Colonies on NMS agar are opaque, have smooth surfaces, are low convex and circular with entire edges, have a butyrous consistency, and are a buff to tan. A diffusible brown pigment may be produced. A bright red prodigiosinelike pigment may also occur. Urease and phosphatase are produced. Esculin is not hydrolyzed. Selenite and triphenyltetrazolium chloride are not reduced. Methane and methanol are the only known sole carbon and energy sources. The $\mathrm{G}+\mathrm{C}$ content of the DNA is 65 to $67 \mathrm{~mol} \%\left(T_{i}\right)$. The type strain is NCIMB 11126 (= ACM $3306=$ ATCC 35069).

Description of the genus Methylocystis gen. nov. (ex Romanovskaya, Malashenko, and Bogachenko 1978). Methylocystis (Me.thyl.o.cys'tis. N. L. n. methylo, methyl group; Gr. n. cystis, bag; N. L. masc. n. Methylocystis, methyl bag). Gram-negative cells that are reniform or coccobacillary and 0.3 to $0.5 \mu \mathrm{m}$ wide by 0.5 to $1.5 \mu \mathrm{m}$ long. Reproduces by normal cell division. Budding division does not occur. Does not form either rosettes or exospores. May form a lipid cyst (55) which is acid fast but does not exhibit heat or desiccation resistance. Nonmotile. Encapsulated. May accumulate poly- $\beta$-hydroxybutyrate and polyphosphate. May form spinae on cell surfaces (18). Contains type II intracytoplasmic membranes which are aligned parallel to the cell wall. Grows at temperatures between 20 and $40^{\circ} \mathrm{C}$; optimal growth occurs at about $30^{\circ} \mathrm{C}$. Grows between $\mathrm{pH} 5.0$ and 9.0; the optimal $\mathrm{pH}$ for growth is about 7.0. Organic growth factors and $\mathrm{NaCl}$ are not required for growth. Strictly aerobic chemoheterotroph. Group II methanotroph. Obligate utilizer of $\mathrm{C}_{1}$ compounds via the serine transhydroxymethylase pathway. Compounds with carbon-carbon bonds are not used as sole sources of carbon and energy. No growth occurs on complex organic media such as nutrient agar. Does not contain the Benson-Calvin cycle for $\mathrm{CO}_{2}$ fixation but contains a complete tricarboxylic acid cycle. Fixes atmospheric nitrogen by means of an aerotolerant nitrogenase. Produces oxidase and catalase. Unable to grow autotrophically or to denitrify. Contains $18: 1 \omega 8 \mathrm{c}$ as the predominant PLFA. The major quinone is ubiquinone 8 (12). The DNA base composition ranges from 62 to $67 \mathrm{~mol} \% \mathrm{G}+\mathrm{C}\left(T_{i}\right)$. Methylocystis parvus is the type species.

Description of Methylocystis parvus sp. nov. (ex Romanovskaya, Malashenko, and Bogachenko 1978). Methylocystic parvus (par'vus. L. masc. adj. parvus, small). The characteristics are the same as the characteristics given in the genus description above, including the following traits. Lipid cysts are formed during stationary phase, but cells do not form spinae. Polyphosphate and poly- $\beta$-hydroxybutyrate accumulate. Colonies on NMS agar are opaque, have smooth surfaces, are low convex and circular with entire edges, have a butyrous consistency, and are pale pink to tan A brown diffusible pigment is often produced. Urease and phosphatase are produced. Esculin is not hydrolyzed. Nitrate is reduced to nitrite. Selenite and triphenyltetrazolium chloride are not reduced. Methane and methanol are the only known carbon and energy sources. The $\mathrm{G}+\mathrm{C}$ content of the DNA is 64 to $67 \mathrm{~mol} \%\left(T_{i}\right)$. The type strain is NCIMB 11129 $(=$ OBBP $=$ ACM $3309=$ IMET $10483=$ ATCC 35066 $)$.

Description of Methylocystis echinoides sp. nov. (ex Gal'chenko, Shishkina, Suzina, and Trotsenko 1977). Methylocystis echinoides (ech.in.oi'des. Gr. adj. echino, hedgehog-like; Gr. suff. ides, similar to; N. L. neut adj. echinoides, spiny like a hedgehog). The characteristics are the same as the characteristics given in the genus description above, including the following traits. Cells are covered with cylindrical spinae (18). Lipid cysts are not formed. Poly- $\beta$-hydroxybutyrate and polyphosphate do not accumulate. Growth on solid NMS medium (solidified with either agar or agarose) is poor. Colonies on NMS agar are pinpoint and opaque, have smooth surfaces, are low convex and circular with entire edges, have a butyrous consistency, and are white. Diffusible pigments are not produced. Nitrate is reduced to nitrite. Urease and phosphatase are not produced. Esculin is not hydrolyzed. Selenite and triphenyltetrazolium chloride are not reduced. Methane and methanol are the only known sole carbon and energy sources. The $\mathrm{G}+\mathrm{C}$ content of the DNA is $62 \mathrm{~mol} \%\left(T_{i}\right)$. The type strain is IMET 10491.

\section{ACKNOWLEDGMENTS}

J.P.B. is indebted to the Department of Education and Training and the University of Queensland for CPRA and APRA funding. The work was partly supported by a CSIRO-university collaborative research award to L.I.S. and P.D.N.

We thank V. A. Romanovskaya and Mary E. Lidstrom, who kindly provided several interesting methanotrophic strains. Likewise, we thank Peter Green (NCIMB Ltd., United Kingdom) and Eugenia Bulygina (University of Minnesota) for their insights into methanotroph systematics. We thank Mandy Watson for this study's lipid analyses.

\section{REFERENCES}

1. Anderson, L. E., and R. C. Fuller. 1969. Photosynthesis in Rhodospirillum rubrum. IV. Isolation and characterization of ribulose-1,5-diphosphate carboxylase. J. Biol. Chem. 244:31053109.

2. Andreev, L. V., and V. F. Gal'chenko. 1978. Fatty acid composition and identification of methanotrophic bacteria. Dokl. Akad. Nauk SSSR 269:1461-1468.

3. Bezrukova, L. V., Y. I. Nikolenko, A. I. Nesterov, V. F. Gal'chenko, and M. V. Ivanov. 1983. Comparative serological analysis of methanotrophic bacteria. Mikrobiologiya 52:800-805.

4. Bowman, J. P., L. Jiménez, I. Rosario, T. C. Hazen, and G. S. Sayler. 1993. Characterization of the methanotrophic bacterial communities present in a trichloroethylene-contaminated subsurface groundwater site. Appl. Environ. Microbiol. 59:23802387. 
5. Bowman, J. P., J. H. Skerratt, P. D. Nichols, and L. I. Sly. 1991. Phospholipid fatty acid and lipopolysaccharide fatty acid signature lipids in methane-utilising bacteria. FEMS Microbiol. Ecol. 85:15-22.

6. Bowman, J. P., L. I. Sly, J. M. Cox, and A. C. Hayward. 1990. Methylomonas fodinarum sp. nov. and Methylomonas aurantiaca sp. nov.: two closely related type I obligate methanotrophs. Syst. Appl. Microbiol. 13:279-287.

7. Bowman, J. P., L. I. Sly, and A. C. Hayward. 1991. Contribution of genome characteristics to the assessment of taxonomy of obligate methanotrophs. Int. J. Syst. Bacteriol. 41:301-305.

8. Bowman, J. P., L. I. Sly, and E. Stackebrandt. 1992. The phylogeny of methanotrophic bacteria based on 16S rDNA sequences, abstr. no. C-97. 7th Int. Symp. Microbial Growth $C_{1}$ Compounds, Warwick, United Kingdom.

9. Bratina, B. J., G. A. Brusseau, and R. S. Hanson. 1992. Use of 16S rRNA analysis to investigate phylogeny of methylotrophic bacteria. Int. J. Syst. Bacteriol. 42:645-648.

10. Bulygina, E. S., K. Chumakov, and A. Netrusov. 1992. Systematics of gram negative methylotrophic bacteria based on $5 \mathrm{~S}$ rRNA sequences, abstr. no. L22. 7th Int. Symp. Microbial Growth $\mathrm{C}_{1}$ Compounds, Warwick, United Kingdom.

11. Bulygina, E. S., V. F. Gal'chenko, N. I. Govorukhina, A. I. Netrusov, D. I. Nikitin, Y. A. Trotsenko, and K. M. Chumakov. 1990. Taxonomic studies on methylotrophic bacteria by $5 \mathrm{~S}$ ribosomal RNA sequencing. J. Gen. Microbiol. 136:441-446.

12. Collins, M. D., and P. N. Green. 1985. Isolation and characterization of a novel coenzyme $\mathrm{Q}$ from some methane-oxidizing bacteria. Biochem. Biophys. Res. Commun. 133:1125-1131.

13. Cox, J. M., and I. C. MacRae. 1989. A numerical taxonomy study of proteolytic and lipolytic psychotrophs isolated from caprine milk. J. Appl. Bacteriol. 66:137-152.

14. Dahl, J. S., K. Mehta, and D. S. Hoare. 1971. New obligate methylotrophs. J. Bacteriol. 109:916-921.

15. Doetsch, R. N. 1981. Determinative methods of light microscopy, p. 21-33. In P. Gerhardt, R. G. E. Murray, R. N. Costilow, E. W. Nester, W. A. Wood, N. R. Krieg, and G. B. Phillips (ed.), Manual of methods for general bacteriology. American Society for Microbiology, Washington, D.C.

16. Duguid, J., B. Marmion, and R. Swain. 1975. Staining of diphtheria bacillus and volutin-containing organisms, p. 41. In R. Cruikshank, J. Duguid, B. Marmion, and R. Swain (ed.), Medical microbiology, 12th ed. Churchill-Livingstone, Edinburgh.

17. Dunkleblum, E., S. H. Tan, and R. J. Silk. 1985. Double-bond location in monounsaturated fatty acids by dimethyl disulphide derivitization and mass spectrometry: application to analysis of fatty acids in pheromone glands of four Lepidoptera. J. Chem. Ecol. 11:265-277.

18. Easterbrook, K. W. 1989. Spinate bacteria, p. 1991-1993. In N. R. Krieg and J. G. Holt (ed.), Bergey's manual of systematic bacteriology, vol. 1. The Williams \& Wilkins Co., Baltimore.

19. Fassel, T. A., M. J. Schaller, M. E. Lidstrom, and C. C. Remsen. 1990. Effect of fixation-resin combinations and ruthenium red on elucidating outer envelope structure and surface morphology of two methanotrophic bacteria. J. Electron Microsc. Tech. 14:52 62.

20. Foster, J. W., and R. H. Davis. 1966. A methane-dependent coccus, with notes on classification of obligate, methane-utilizing bacteria. J. Bacteriol. 91:1924-1931.

21. Gal'chenko, V. F., and A. I. Nesterov. 1981. Numerical analysis of protein electrophoretograms of obligate methanotrophic bacteria. Mikrobiologiya 50:725-730.

22. Gal'chenko, V. F., V. N. Shishkina, N. E. Suzina, and Y. A. Trotsenko. 1977. Isolation and properties of new strains of obligate methanotrophs. Mikrobiologiya 46:723-728.

23. Green, P. N. 1992. Taxonomy of methylotrophic bacteria, p. 23-84. In J. C. Murrell and H. Dalton (ed.), Methane and methanol utilizers. Plenum Press, New York.

24. Guckert, J. B., D. B. Ringleberg, D. C. White, R. S. Hanson, and B. J. Bratina. 1991. Membrane fatty acids as phenotypic markers for the polyphasic approach to taxonomy of methylotrophs within the Proteobacteria. J. Gen. Microbiol. 137:2631-2641.
25. Hanson, R. S., and J. A. Phillips. 1981. Chemical composition, p. 328-364. In P. Gerhardt, R. G. E. Murray, R. N. Costilow, E. W. Nester, W. A. Wood, N. R. Krieg, and G. B. Phillips (ed.), Manual of methods for general bacteriology. American Society for Microbiology, Washington, D.C.

26. Hanson, R. S., and E. V. Wattenberg. 1991. Ecology of methylotrophic bacteria, p. 325-348. In I. Goldberg and J. S. Rokem (ed.), Biology of methylotrophs. Butterworth-Heinemann, London.

27. Huss, V. A. R., H. Festl, and K. H. Schleifer. 1983. Studies on the spectrophotometric determination of DNA hybridization from renaturation rates. Syst. Appl. Microbiol. 4:184-192.

28. Jenkins, O., and D. Jones. 1987. Taxonomic studies on some Gram-negative methylotrophic bacteria. J. Gen. Microbiol. 133: $453-473$.

29. Lanyi, B. 1987. Identification methods for important bacteria. Methods Microbiol. 19:105-160.

30. Lapage, S. P., P. H. A. Sneath, E. F. Lessel, V. B. D. Skerman, H. P. R. Seeliger, and W. A. Clark (ed.). 1975. International code of nomenclature of bacteria. 1976 Revision. American Society for Microbiology, Washington, D.C.

31. Large, P. J., and J. R. Quayle. 1963. Microbial growth on $C_{1}$ compounds. V. Enzyme activities in extracts of Pseudomonas AM1. Biochem. J. 87:386-395.

32. Liang, J., and Z. Chen. 1983. A new genus of bacteria: Echinosporobacterium album. Microbiol. Sinica 23:193-196.

33. Lidstrom, M. E. 1988. Isolation and characterization of marine methanotrophs. Antonie van Leeuwenhoek 54:189-199.

34. Lysenko, A. M., V. F. Gal'chenko, and N. A. Chernykh. 1988. Taxonomic study of obligate methanotrophic bacteria using the DNA-DNA hybridization technique. Mikrobiologiya 57:653658.

35. Malashenko, Y. R., V. A. Romanovskaya, V. N. Bogachenko, and A. D. Shved. 1975. Thermophilic and thermotolerant methane-assimilating bacteria. Mikrobiologiya 44:855-862.

36. Meyer, J., R. Haubold, J. Heyer, and W. Böckel. 1986. Contribution to the taxonomy of methanotrophic bacteria: correlation between membrane type and GC-value. Z. Allg. Mikrobiol. 26:155-160.

37. Moore, W. E. C., and L. V. H. Moore. 1990. Index of the bacterial and yeast nomenclatural changes published in the International Journal of Systematic Bacteriology since the 1980 Approved Lists of Bacterial Names (1 January 1980 to 1 January 1989). American Society for Microbiology, Washington, D.C.

38. Nichols, P. D., J. B. Guckert, and D. C. White. 1986. Determination of monounsaturated bond position and geometry for microbial monocultures and complex consortia by capillary GC-MS of their dimethydisulphide adducts. J. Microbiol. Methods 5:49-55.

39. Nichols, P. D., G. A. Smith, C. P. Antworth, R. S. Hanson, and D. C. White. 1985. Phospholipid and lipopolysaccharide normal and hydroxy fatty acids as potential signatures for methaneoxidizing bacteria. FEMS Microbiol. Ecol. 32:327-335.

40. Pierson, B. K., S. J. Giovannoni, and R. U. Castenholtz. 1984. Physiological ecology of a gliding bacterium containing bacteriochlorophyll $a$. Appl. Environ. Microbiol. 47:576-584.

41. Rogosa, M., M. I. Krichevsky, and R. R. Colwell. 1986. Coding microbiological data for computers. Springer-Verlag, New York.

42. Romanovskaya, V. A. 1984. Methylovarius gen. nov., a new genus. Mikrobiologiya 53:640-646.

43. Romanovskaya, V. A., Y. R. Malashenko, and V. N. Bogachenko. 1978. Corrected diagnoses of the genera and spe cies of methane-utilizing bacteria. Mikrobiologiya 47:96-103.

44. Romanovskaya, V. A., Y. R. Malashenko, and N. I. Grishchenko. 1981. Diagnosis of methane-oxidizing bacteria by numerical methods based on cell fatty acid composition. Mikrobiologiya 49:762-764.

45. Sieburth, J. M., P. W. Johnson, M. A. Eberhardt, M. E. Sieracki, M. E. Lidstrom, and D. Laux. 1987. The first methaneoxidizing bacterium from the upper mixing layer of the deep ocean: Methylomonas pelagica sp. nov. Curr. Microbiol. 14: 285-293. 
46. Sly, L. I. 1982. The use of disposable gas generating kits for the growth of hydrogen-oxidizing bacteria and the determination of hydrogen autotrophy. J. Microbiol. Methods 3:7-14.

47. Smibert, R. M., and N. R. Krieg. 1981. General characterization, p. 409-443. In P. Gerhardt, R. G. E. Murray, R. N. Costilow, E. W. Nester, W. A. Wood, N. R. Krieg, and G. B. Phillips (ed.), Manual of methods for general bacteriology. American Society for Microbiology, Washington, D.C.

48. Sneath, P. H. A., and R. R. Sokal. 1973. Numerical taxonomy: the principles and practice of numerical classification. W.H. Freeman \& Co., San Francisco.

49. Sokolov, I. G., V. A. Romanovskaya, Y. B. Shkurko, and Y. R. Malashenko. 1980. Comparative characterization of the enzyme systems of methane-utilizing bacteria that oxidize $\mathrm{NH}_{2} \mathrm{OH}$ and $\mathrm{CH}_{3} \mathrm{OH}$. Mikrobiologiya 49:142-148.

50. Staley, J. T. 1968. Prosthecomicrobium and Anacalomicrobium: new freshwater prosthecate bacteria. J. Bacteriol. 95:19211942.

51. Takeda, K. 1988. Characteristics of a nitrogen-fixing methanotroph, Methylocystis T-1. Antonie van Leeuwenhoek 54:521534.

52. Tsuji, K., H. C. Tsien, R. S. Hanson, S. R. dePalma, R. Scholtz, and S. LaRoche. 1990. 16S ribosomal RNA sequence analysis for determination of phylogenetic relationships among methylotrophs. J. Gen. Microbiol. 136:1-10.

53. Vela, G. R., and O. Wyss. 1964. Improved stain for the visualization of Azotobacter encystment. J. Bacteriol. 87:476-477.

54. White, D. C., R. J. Bobbie, J. S. Herron, J. D. King, and S. J. Morrison. 1979. Biochemical measurements of microbial biomass and activity from environmental samples, p. 69-81. In J. W. Costerton and R. R. Colwell (ed.), Native aquatic bacteria: enumeration, activity and ecology. Publication ASTM STP695. American Society for Testing and Materials, Philadelphia.

55. Whittenbury, R., S. L. Davies, and J. F. Davey. 1970. Exospores and cysts formed by methane-utilizing bacteria. J. Gen. Microbiol. 61:219-226.

56. Whittenbury, R., and N. R. Krieg. 1984. Family IV. Methylococcaceae, p. 256-261. In N. R. Krieg and J. G. Holt (ed.), Bergey's manual of systematic bacteriology, vol. 1. The Williams \& Wilkins Co., Baltimore.

57. Whittenbury, R., K. C. Phillips, and J. F. Wilkinson. 1970. Enrichment, isolation and some properties of methane-utilizing bacteria. J. Gen. Microbiol. 61:205-218. 